\title{
A Glance at the Complexity of Nutrition and the Prostate: Considering Molecular Targets to Unravel the Most Recent Controversy Between Omega-3 Fatty Acids and Their Impact on Prostate Cancer Risk
}

\author{
Gailene Tobin, Robert Hurta and Marianna Kulka \\ Additional information is available at the end of the chapter
}

http://dx.doi.org/10.5772/55858

\section{Introduction}

\subsection{Pathophysiology of prostate cancer}

Considered part of both the male reproductive and urinary systems, the prostate gland (or prostate) is oval shaped, and is variable in size (ranging from 20 - 30 grams in adult males)[1]. The prostate gland consists of different types of cells, including gland (epithelial) cells, muscle cells and fibrous cells [2]. The overall structure of the prostate is divided in two ways: by zone, a classification more often used in pathology $[2,3]$ or by lobe, more often used in anatomy [2]. Prostate associated diseases usually present with urinary and sexual dysfunction and the initial symptoms related to such often necessitate diagnostic testing to indicate the presence of a certain disease state $[4,5]$. Although the accuracy and use of Digital Rectal Examination (DRE) and Prostate Specific Antigen (PSA) remains controversial, these tests can be used alone, or in combination, to detect benign conditions (including benign prostatic hyperplasia (BPH) and prostatitis) or predict most forms of PCa [6, 7]. Subsequent prognosis of PCa is confirmed by prostate biopsy and involves pathological staging (Tumor/ Nodes/ Metastasis (TNM) System) and grading (Gleason Score) [8-10]. Broadly defined as the malignant growth of cells of the prostate gland, PCa occurs in many different zones of the prostate [1, 11, 12]. PCa (mostly 75\%) arise in the peripheral zone, and to a lesser extent in the central and transitional zones [13]. Similar to the pattern of most epithelial cancers, cells within the prostate undergo an accumulation of genetic changes whereby the functions of cellular control are lost as the cell and tissue undergo phenotype changes from normal to prostatic intraepithelial neoplasia (PIN) [14]. This 
progressively leads from to an acute high-grade PIN (HGPIN) to superficial cancers, and then to invasive disease $[11,12]$ (See Figure 1). The most common form of PCa (around 95\%) originates in the glandular/epithelial tissue, and is coined prostatic adenocarcinoma; thus, this term has emerged synonymously with PCa [13]. The residual forms of PCa are termed nonadenocarcinoma, and present as less commonly occurring cancers, but are often more aggressive. Such can be categorized as epithelial (such as squamous cell carcinoma) and nonepithelial (such as osteo- and angio-sarcoma), and also include others which rarely develop in the prostate and are derived from primary tumors of the bladder and urethra (such as transitional cell carcinoma) [13]. The diagram below gives a general overview of prostate location, the division of zones and the general progression of PCa as the cell and tissue phenotype changes from normal to A. prostatic intraepithelial neoplasia (PIN), to B. increasing and severe high-grade PIN (HGPIN), then to C. superficial cancers, and finally to D. invasive disease $[11,12,15]$.

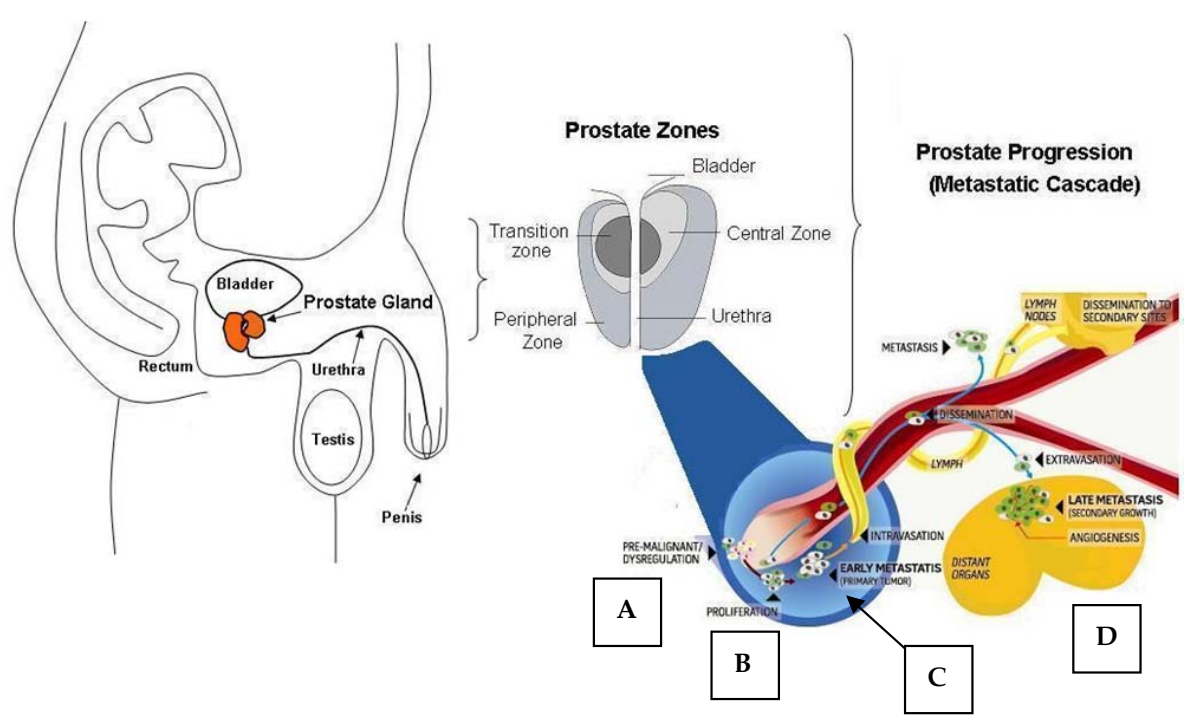

Figure 1. GA Tobin, 2011. An Overview of the Pathogenesis of PCa.

While the specific causes of PCa remain unknown, the only established risk factors for PCa are age, race and family history [16]. However, it is well accepted that the stimulation of androgens over a prolonged period contributes to the development of $\mathrm{PCa}$ [17]; thus, the androgen receptor (AR), along with its various cofactors play an important role in PCa. Nonetheless, progression of $\mathrm{PCa}$ to androgen independence (or the hormone refractory state) is one of the primary reasons for PCa-related deaths today [18]. PCa is the sixth most commonly diagnosed cancer worldwide [19]. For Canadian men, PCa is the most prevalent (based on 15 years) and frequently diagnosed non-dermatological cancer [20]. Like most other solid malignancies, PCa 
can extend to distant organs such as the liver, lungs and brain, with an abnormally high tendency for metastasizing to the bone [21, 22]. When distant metastasis occurs, the 5 year survival rate drops to 31\% [20]. Although Prostate Specific Antigen (PSA) values, TNM staging, Gleason Score, and tumor biomarkers are considered significant in their ability to predict patient outcome, alone or when incorporated into various nomogram models, there is much controversy about their accuracy. Nonetheless, treatment regimens are largely based on these combined indicators.

Standard treatments for PCa can range from watchful waiting to surgery, radiation therapy, hormone therapy, chemotherapy, and biological therapy, alone or in combination [23-26]. Additionally, in North America, a minimum of $30 \%$ of men with diagnosed prostate disease choose to use complementary and/or alternative medical (CAM) therapy [27, 28] including primarily herbal biological agents, vitamins, supplements and dietary intervention [29]. This trend is likely due to progressive research on differences in global distribution, indicating that prolonged diet and micronutrient intake intervals may possibly control whether PCa remains latent or develops into a clinically significant disease [30-34]. In particular, the role of polyunsaturated fatty acids (PUFA) has gained considerable importance in PCa in the last several years. However, the molecular basis for these observations has not been fully explained. Genetic (and epigenetic) alterations and specific signaling pathways [35] are considered important in the multi-step process of cancer [36]. Thus, dietary interventions which target signaling pathways and downstream genes known to be impacted in PCa may be a worthwhile and effective approach in developing novel therapies.

\section{Endocrine and molecular biology and controls in prostate cancer}

\subsection{Hormones and prostate cancer}

Charles Huggins introduced the phenomenon of androgen removal as a plausible means for prostate cancer treatment in men after his observation that castration in canines caused shrinkage of prostate tumors [37]. Similar to normal prostate cells, prostate cancer cells are androgen dependent at the outset with a normally functioning androgen receptor (the receptor only responds to androgen) [37]. These initial studies on the dependence of the prostate gland on androgens formed the principle behind androgen deprivation therapy. There are several avenues that can be utilized to remove androgens, and the decision to do so is largely dependent on the stage or severity of cancer. Early cancers commonly target 5 alpha( $\alpha)$-reductase inhibition in an effort to decrease levels of the active hormone dihydrotestosterone (DHT). In fact, in the Prostate Cancer Prevention Trial (PCPT), finasteride (a $5 \alpha$-reductase inhibitor) has been reported to lower the incidence of prostate cancer in men by $25 \%$ [38]. The initial concern about finasteride causing more severe cancers was refuted. However, despite this, the FDA has published advice concerning the use of finasteride and an increased risk of high-grade PCa [39]. Interestingly, the PCPT study is the one which Brasky et al. used to extrapolate data for their recent findings regarding n-3 PUFA and prostate cancer [40]. AR antagonists can also be used to block both testicular and adrenally produced androgens from binding to the androgen 
receptor and initiating gene transcription [41]. Additionally, testicular-derived androgen production can be blocked by luteinizing hormone (LH) inhibition [42]. For more aggressive cancers, these previously mentioned methods can be used in combination blocking both androgen production and their actions [41].

Despite the fact that most prostate cancers respond well to androgen deprivation, prostate cancer cells develop survival mechanisms involving the androgen receptor that can render these treatments ineffective; this represents the progression from androgen sensitive to androgen insensitive disease. Central to this role, the AR develops abnormal signaling functions that are not seen in normal AR signaling in androgen sensitive prostate cancer progression. There are several mechanisms through which the androgen receptor can participate in androgen insensitive prostate cancer. Amplification of the AR creates a hypersensitivity to even low amounts of circulating androgens [43]. The AR can also become promiscuous; mutations of the ligand binding domain can allow for aberrant AR activation by factors other than androgens (i.e: estrogen or other steroid hormones) and increased AR activity can also occur when such mutations are found in coregulators [44]. The AR can become an outlaw receptor - receptive to transactivation, phosphorylation and activation by other signaling pathways and peptide growth factors (i.e: insulin growth factor -1 (IGF-1) in the absence of androgen [45]. Other modified functions of the AR include activation of other proproliferative and anti-apoptotic factors that can bypass the AR pathway, eliminating any dependence on androgens for these physiological effects. For example: bcl-2, an anti-apoptotic protein, is not expressed in normal prostate epithelium, however in the absence of AR function, bcl-2 is produced [46]. Thus, effective treatment is dependent in the ability of the AR to develop these modified survival mechanisms.

The topic of testosterone production is worthy outside the realm of AR function in androgen insensitive prostate cancer. It is well known that the testes are the main site of testosterone production. Therapies that reduce testosterone production by targeting the testes do not affect adrenal androgen synthesis which is increased in androgen insensitive prostate cancer, thus compensating for the reduced testicular androgen production. In such cases, a broad spectrum cytochrome P450 inhibitor may be recommended, although their use may introduce side effects so extensive that their utility is limited [47].

\subsection{Molecular biology of prostate cancer}

Hanahan and Weinberg, in 2011, summarize the unique biological capabilities of cancer [48]. The hallmarks of cancer outlined within include sustaining proliferative signaling, evading growth suppressors, resisting cell death, enabling replicative immortality, inducing angiogenesis, and activating invasion and metastasis. Interestingly, in this updated review, genomic stability and inflammation are noted as underlying these characteristics as they expedite acquisition and foster multiple functions, respectively. Additionally, two emerging hallmarks - reprogramming of energy metabolism and evading immune destruction are discussed, as well as the dimensions of tumor complexity including the ability of these acquired traits to create the tumor microenvironment [48]. We agree that the recognition of all of these concepts, alone or in combination, provide guidance in the development of new cancer treatments. The 
paragraphs to follow are meant to provide a basic overview of some of the aforementioned concepts and their relevance in prostate cancer. While we have not specifically discussed tumor microenvironment or two of the above-mentioned emerging hallmarks and their relevance to prostate cancer in this chapter, such topics of importance subsequently emerge in broader areas of discussion.

\subsubsection{Sustaining proliferative signaling}

Although the host may provide a source of growth factors, such are not essential for the survival of cancer cells. Cancer cells can evade the requirement for exogenous growth factors in several ways, including the production of their own growth factors. Cancer cell mutations can result in constitutively active growth factors and growth factor receptor pathways. Thus the initiation of the signaling cascade occurs without the required binding of the growth factor ligand to the receptor; cell growth occurs in the absence of ligand. In this regard, mutations in both the ras family and epidermal growth factor (EGF) receptors are seen in prostate cancer [49]. Another example of such includes autocrine and/or paracrine production of IGF-1 by prostate cancer cells [50], as stromal prostate cancer cells and the adjacent epithelium produces IGF-1 and expresses IGF-1 receptor, respectively.

\subsubsection{Evading growth suppressors}

Pathway hypersensitivity can result when cancer cells over-express growth factor receptors in the presence of normal physiological levels of a growth factor. PCa cells frequently increase their expression of Human Epidermal Growth Factor Receptor (HER)2 and the androgen receptor [51]. In this way, small amounts of androgen that can direct large increases in the expression of pro-carcinogenic genes or AR regulated gene expression can even occur in the absence of androgens.

\subsubsection{Resisting cell death}

The body eliminates damaged or dysregulated cells through intrinsic mechanisms including tumor suppressor pathways responsible for the mediation of DNA repair, cell cycle arrest, apoptosis and senescence [52]. However, some of these damaged cells harbor mutations and/ or have the ability to produce factors that allow them to survive. Proliferation of these cells, if not kept in check, results in tumors. The expression of Bcl-2, an anti-apoptotic protein indicates that a cell may not respond to cell death cues. Production of Bcl-2 is high in prostate cancer cells [46], rendering them resistant to apoptosis.

\subsubsection{Enabling replicative immortality}

The balance between growth and anti-growth signaling results in normal cell growth. Differentiation of cells occurs only when cells halt the growth program. Thus, rapidly proliferating (undifferentiated) cells form a mass of cells commonly referred to as a tumor. Such unimpeded 
growth is usually less differentiated than normal cells. Under normal conditions, transforming growth factor beta (TGF $\beta$ ) is an anti-growth factor stimulating epithelial cells to a terminally differentiated state. However, this property is dysregulated in prostate cancer development [53]. As TGF- $\beta$ signals through retinoblastoma $(\mathrm{Rb})$ tumor suppressor gene [54], it is assumed to cause an increase in cell cycle inhibitors, such as $\mathrm{p} 21$. Thus, the loss of Rb in prostate cancer renders the pro-differentiation, anti-proliferation effects of TGF- $\beta$ null [55].

The ability of cancer cells to replicate many more times over their natural lifespan distinguishes them from normal cells. Inherent defects in prostate cancer cells, such as losses of cell cycle inhibitors, including p21 or p27 enable this phenomenon. As with other cancer cell types, dysregulated telomere maintenance provides another explanation. The small DNA fragments at the ends of chromosomes are known as telomeres [56]. Telomere shortening to a desired length, following cell reproduction, signals a cell to stop replicating. However, cancer cells express elevated levels of telomerase, thus allowing cancer cells to replicate beyond their normal programmed number of replications by maintaining telomere length [38].

\subsubsection{Inducing angiogenesis, activating invasion and metastasis}

In order to expand in size, cancer cells require the support of a vasculature system. Judah Folkman's pioneering work in cancer revealed this unconditional requirement for sustained angiogenesis in cancer [57], accompanied by increased requirements for oxygen and nutrient supply, as well as waste removal; the latter is due to the ability of cancer cells to rapidly proliferate. In prostate cancer, and other cancers, vascular endothelial growth factor (VEGF) production is elevated [58]. This paracrine factor stimulates nearby endothelial cells and epithelial cells to form irregular vasculature associated with tumorigenesis. This confirms the notion that cancer cells produce factors that recruit endothelial progenitor cells and epithelial cells are capable of forming primitive vascular channels.

To further survive along the cancer cascade, and even in the presence of increased angiogenesis, cells must metastasize as the tissue of origin is capacity limiting with respect to tumor burden [57]. Metastasis of cancer cells involves degradation of the basement membrane at the site of origin and penetration to the bloodstream and/or lymph. Although few cells survive this journey through the lymph and blood stream, those that penetrate into the tissue of destination complete the metastatic cascade by invading and colonizing to secondary sites.

Cadherins, a class of membrane receptors, can undergo isoform switching (known as "cadherin switching") during normal development which allows cell types to segregate from one another. Within this family, particular cadherin members promote cell motility and invasion control via growth factor receptor signaling and pathway signaling components [59]. In tumor cells, this activity ceases resulting in aggressive tumor cells with an ability to escape the origin of the tumor and metastasize.

Therefore, the functional significance of these specific cadherins and cadherin switching provides insight into the molecular mechanism underlying tumor progression and offers an opportunity for the development of novel molecular targets for anti-cancer therapy. Integrity 
of the basement membrane and maintenance of epithelial integrity involves E-cadherin (epithelial calcium-dependent adhesion), a Type 1 transmembrane protein. The extracellular component of E-cadherin is responsible for homophilic interactions, while the cytoplasmic component of E-cadherin binds to beta $(\beta-)$ and gamma $(\gamma-)$ catenin [60]. While the loss of Ecadherin signifies the ability of a cancer cell to leave the prostate [61], it would be remiss to think that this loss alone is responsible for tumor cell invasion considering the dimensions of tumor microenvironment [48]. Aside from changes in cell-to-cell and cell-to-matrix adhesion, tumor invasion involves additional cellular events including cell migration and proteolytic degradation of the extracellular matrix (ECM), and other events which alone or in combination can affect cell signaling pathways. The initial suggestion that E-cadherin downregulation may result in the activation of specific signaling pathways triggering tumor cell invasion has been explored. Because of its dual role as a cytoplasmic cellular adhesion complex component and its fundamental role in Wnt-mediated signal transduction, $\beta$-catenin has emerged as a prime contender for activating such signaling pathways. Additionally, levels of matrix metalloproteases (MMPs) also increase in prostate cancer and degrade stromal and basement membrane components, enabling cancer cells to escape the tissue of origin [62]. Overall, such factors that allow the progression of the metastatic cascade, rather than the original tumor, are responsible for cancer death.

\subsubsection{Inflammation}

Although inflammation has been long recognized in the development of cancer [63, 64], chronic inflammation has emerged as one of the enabling characteristics of human cancer [48]. Chronic inflammation can be caused by numerous factors including infectious and non-infectious agents and / or other environmental aspects including hormonal changes and dietary interventions $[65,66]$. Fostering multiple functions related to cancer, inflammation cuts across broad areas of study including genetics, epidemiology, molecular pathology, histopathology, immunology and animal modelling to name a few. In other words, it would be difficult to capture an association between cancer and inflammation by way of any one over-arching theory. A diverse amalgamation of evidence exist which points to the role of the inflammatory response in physiological maintenance including tissue homeostasis and the healing process involved succeeding injury or damage. Rakoff-Nahoum (2006) has provided an excellent overview of this dual role of inflammation in tumor development [52]. The inter-relationship of cancer and inflammation with respect to inflammatory cells (and their mediators) and signaling pathways involved that have been published in the past suggests that the inflammatory system can affect tumor development and inhibit the development of cancer [67-72]. The topic of inflammation in prostate carcinogenesis has been recently updated in a thorough review authored by Sfanoes and DeMarzo (2012) encompassing recent advances in prostate risk and development with respect to prostatic inflammation stimuli, immunobiology, inflammatory pathways and cytokines, proliferative inflammatory atrophy as a risk factor lesion to prostate cancer development, and the role of nutritional or other anti-inflammatory compounds [66]. While this exceptional review articulates the vast effects of inflammation in prostate cancer, we will aim to highlight evidence to date as related to some promising antiinflammatory natural products while focusing on PUFA. 


\section{Promising anti-inflammatory natural products in PCa}

The role of inflammation in prostate cancer etiology stems from studies accessing the relationship between intake of anti-inflammatory dietary compounds and prostate cancer risk. Epidemiological evidence associates or significantly correlates consumption of tomato [73], soy and green tea $[74,75]$ with decreased prostate cancer risk. Furthermore, animal studies confirm that the anti-inflammatory properties of both soy and green tea cause a decrease in prostate cancer [74, 75]. One study involving Transgenic Adenocarcinoma of the Mouse Prostate (TRAMP) mice fed a diet enriched with processed whole tomatoes reported benefits including increased survival, delayed progression from PIN to PCa cancer and a decreased incidence of poorly differentiated PCa cancer [76]. Prostate cancer cell lines treated with phytoestrogens, specifically genistein and daidzein, indicate a decrease in prostate cancer risk, however this effect seems to be linked to epigenetic modifications of DNA [77].

\subsection{PUFA and prostate cancer}

Interest in dietary fats and disease etiologies has emerged because of their known antiinflammatory properties. Examples of dietary fat which are essential in a variety of mammalian biological processes and impact PCa include omega-3 (n-3) and omega-6 (n-6) PUFA [78, 79]. In published cell line and xenograft studies, n-6 PUFA (linoleic acid and arachidonic acid) typically exert a growth-promoting effect, while n-3 PUFA (EPA and DHA) have growthinhibitory effects [80-85]. In vitro and animal studies suggest a trend of opposite effects for cancer development with respect to n-3 and n-6 PUFA. The n-3 PUFA, such as EPA and DHA, indicate a suppression of tumor carcinogenesis, however n-6 PUFA seems to promote tumor development. From an epidemiological perspective, evidence of an association between particular PUFA and PCa is inconsistent, with many studies reporting no association between dietary intake of n-3 or n-6 PUFA and the risk of PCa [86-92], however both pre-clinical in vivo and in vitro studies clearly indicate that there are biological mechanisms by which omega-3 PUFA can arrest growth in both PCa cells and tumors. Supplementation of n-3 PUFA in animal studies failed to produce an effect on prostate tumor growth or other markers of PCa progression and did not significantly reduce tumor growth in a PCa mouse model [93-96]. Treatment of human PCa cells with n-3 PUFA has been shown to consistently inhibit proliferation and /or increase programmed cell death, affect gene expression and deter properties of invasive human PCa in cells supporting the notion that EPA and DHA supplementation could preclude or limit the growth of prostate tumors [80, 85, 94, 97-102]. In general, and as found in a recent case-control study, while proinflammatory n-6 PUFA may present an increase in PCa risk, the anti-inflammatory properties of n-3 PUFA have been noted in their association with decreased risk [103]. Interestingly, this same study reported that mutations in the inflammation and mitogenesis related gene (COX-2), combined with low nutritional consumption of n-3 PUFA, had a higher risk of PCa; this risk was lowered with an increase in the dietary intake of n-3 PUFA [103]. Inflammatory gene expression is usually negatively associated with cancer stage and prognosis [104]. Despite these trends, a recent epidemiology study by Brasky (2011) contradicts the protective role of n-3 PUFA in PCa by reporting a positive association with 
DHA for high-grade disease[40]. Specifically the findings indicate that higher blood concentrations of n-3 PUFA are associated with increased risk of high-grade prostate cancer (Gleason score 8-10), and higher concentrations of n-6 PUFA were associated with decreased risk [40]. Dr. Brasky has indicated that these findings "turn what we know-or rather what we think we know-about diet, inflammation and the development of prostate cancer on its head and shine a light on the complexity of studying the association between nutrition and the risk of various chronic diseases [105]." Could it be that what is deemed good and promoted for heart and brain health may be essentially harmful to the prostate? Consider the following: Data analyzed to come to this vastly different conclusion was based on a subset of more than 3200 (half of which developed PCa throughout the duration of the study) from the overall study population of 19,000 [40]. This nationwide randomized clinical trial was initiated to test the efficacy of the drug finasteride to prevent prostate cancer and considered unique as biopsy was used to confirm the absence or presence of prostate cancer in all study subjects [105]. The original intent of the study was to prove the hypothesis that n-3 PUFA would reduce and n-6 PUFA and transfatty acids would increase prostate cancer risk, pre-empted by two important known factors; that n-3 fatty acids originating mainly in fish and their oil supplements have anti-inflammatory properties and chronic inflammation is known to increase the risk of several cancers. All this combined with an inconsistent history of studies and the fact that the mechanisms behind the influence of n- 3 PUFA on the risk of developing high-grade PCa have not been identified, warrants further research. Nonetheless, we are presented with evidence of substantive biological activity, and thus we must explore other mechanisms, aside from inflammation, that may play a greater role in the development of certain prostate cancers. To embark upon this currently debatable journey, there are key factors concerning prostate cancer and dietary interventions that should be considered, particularly n-3 PUFA. The sections to follow are meant to generate, by example and based on the current literature, some thoughts on how to proceed in this area of research to determine the actual role of n-3 PUFA in prostate cancer.

\section{Looking forward: Considerations for further research in n-3 PUFA and prostate cancer}

\subsection{Prostate cancer signaling pathways and n-3 PUFA}

Signaling pathways and their associated molecules often have a dual role in events such as homeostasis, tissue repair, and tumorigenesis. For example, the Wnt/ $\beta$-catenin pathway is critical in maintaining steady-state proliferation and tumorigenesis of tissues [106]. Numerous studies to date indicate that n-3 PUFA treatment can affect cell signaling partially through AKT (protein kinase B), mTOR (mammalian target of rapamycin) and NF- $\kappa \mathrm{B}$ (nuclear factor kappa B) associated pathways [94, 95, 99, 107]. Treatment with n-3 PUFA has been indicated in the inhibition of human hepatocellular carcinoma and cholangiocarcinoma cell growth by blocking the Wnt/ $\beta$-catenin pathway $[108,109]$, and DHA treatment has been shown to inhibit the production of $\beta$-catenin in colon cancer cells [110-112]. However, the effects of n-3 PUFA on Wnt/ $\beta$-catenin signaling in PCa remain largely unknown. A single study in PCa indicates 
that fat-1 gene (cloned from Caenorhabditis elegans) that encodes for a n-3 PUFA desaturase (which converts n-6 PUFA to n-3 PUFA) expression was shown to reduce phosphorylation of

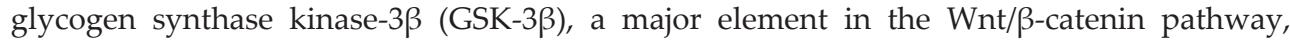
resulting in subsequent down-regulation of both $\beta$-catenin and cyclin D1 thereby inhibiting PCa cell proliferation [113].

\subsubsection{An introduction to Wnt/ $\beta$-catenin signaling}

The Wnt family constitutes 19 highly conserved glycoprotein members in mammals [114]. The most significant molecule implicated in the canonical Wnt cascade is $\beta$-catenin, a cytoplasmic protein regulated by a multi-protein destruction complex made up of Axin, adenomatous polyposis coli (APC), GSK-3 $\beta$ and casein kinase 1 (CK1) [115]. In the absence of Wnt signaling, the destruction complex stimulates the phosphorylation of $\beta$-catenin by GSK-3 $\beta$, leading to subsequent ubiquitination and proteasomal degradation [116, 117]. Conversely, in the presence of Wnt signaling, Wnt ligand-frizzled (FZD) binding causes disheveled (DVL) protein dissociation of the $\beta$-catenin destruction complex, blocking the phosphorylation of $\beta$-catenin, and leading to $\beta$-catenin accumulation in the nucleus [116, 117]. Nuclear $\beta$-catenin functions as a transcription co-factor of the Tcf/Lef family and leads to the activation of Wnt target genes implicated in cell proliferation, differentiation and apoptosis, including c-myc, cyclin D1, Akt, MMP-7, and AR [114, 116-122].

\subsubsection{Using Wnt/ $\beta$-catenin signaling as a model to determine the pathogenic role of $n-3$ PUFA in prostate cancer}

Modular in nature, the activity of the Wnt/ $\beta$-catenin pathway can be modified through several points of intervention. The fundamental event in $W n t / \beta$-catenin signaling occurs in the nucleus and is the result of stabilized $\beta$-catenin recruiting Tcf/Lef transcription factors that modulate the expression of oncogenes, such as c-myc and cyclin D1[123-128]. Abnormal expression of $\beta$-catenin has been observed in up to $71 \%$ of prostate tumor specimens [129-131], is elevated in more than $20 \%$ of advanced prostate tumors [132] and is associated with advanced stage PCa [130, 133, 134]. APC alterations alone are considered prognostic with respect to an unfavorable outcome [135] even though it varies with respect to inactivation in PCa reporting somatic loss ranging from $2-43 \%[132,136-138]$ and promoter hypermethylation in up to $90 \%$ of PCa $[135,139,140]$. Mutations in Axin-1 have been identified in $14 \%$ of advanced PCa, and several Axin-1 mutations and polymorphisms have been noted in PCa cell lines [138]. DVL-1, is a pathway regulator involved in Axin recruitment and inactivation, is significantly overexpressed in PCa and has also shown a positive correlation with PCa grade [141]. Pathway activators, including WNT-1, $-2,-5 \mathrm{~A}$, and -6 have been highly overexpressed in primary PCa compared to normal prostate [142-145], and WNT-1 and -2 have been indicated as having a role in invasive PCa $[143,146]$. Conversely, but also resulting in stabilized $\beta$-catenin, pathway inhibitors are commonly downregulated in PCa. Dickkopf-related protein (DKK)-1 expression is lower in PCa tissue in comparison to normal prostate tissue samples and furthermore is significantly reduced during progression to metastasis [143, 147]. Secreted frizzled-related protein (SFRP)- 1 and DKK-3 show decreased expression in prostate tumor cells [148-151] 
Downregulation of SFRP-1 was also reported in PCa cell lines [152]. It is interesting to note that SFRP-4 overexpression is associated with decreased proliferation, decreased anchorageindependent growth and decreased invasiveness in a PCa cell line, and additionally predicts a good prognosis in PCa [153, 154]. WIF-1, another Wnt antagonist is downregulated at the mRNA (23\%) and protein level (64\%) of PCa [155]. Recently, FZD-3 inhibition by soy protein was shown to suppress the growth of PCa cell lines [156]. Similarly, FZD-5 was highly upregulated in the prostate tissue of advanced PCa cancer patients and was downregulated by zoledronic acid in PC3 cells, but not DU145 cells [157]. Appropriate steps to determine the role of n-3 PUFA in prostate cancer may include investigating whether n-3 PUFA treatment will affect subcellular gene expression and localization of $\beta$-catenin. Beyond confirmation of the molecular mechanism(s) by which n-3 PUFA inhibits Wnt $/ \beta$-catenin, subsequent experiments could target degradation of cytoplasmic $\beta$-catenin and activation of the Wnt receptor complex. Table 1 summarizes dysregulation of numerous pathway components which may be responsible for PCa tumor development/progression and as such represents potential targets for further investigation to determine n-3 PUFA/Wnt/ $\beta$-catenin interactions in PCa.

\subsubsection{Clinical significance of targeting the Wnt/ $\beta$-catenin pathway in PCa with $n-3$ PUFA}

Despite the noted progress of hormone-based drugs as a therapy, PCa remains as one of the primary causes of cancer deaths worldwide [20,101]. Thus, new and improved therapeutic strategies to prevent PCa and inhibit its progression are needed. In this regard, n-3 PUFA presents tremendous opportunity as a therapeutic intervention in PCa. There is enough convincing data available to show a positive correlation between $\mathrm{Wnt} / \beta$-catenin activation and PCa progression. It is also well established now that n-3 FAs supplementation can impact PCa development and progression in vitro. However, whether these effects of $n-3$ PUFA on PCa can occur at least in part through inhibition of $\mathrm{Wnt} / \beta$-catenin signaling remain largely unknown. Thus, the incorporation of variations as suggested above could start by targeting nuclear interaction and progressing back through the pathway to the point of surface expression interactions of the Wnt-FRZ-LRP Receptor Complex. Furthermore, AR expression is positively correlated with an increase in cytoplasmic/nuclear $\beta$-catenin levels in epithelial cells of the prostate [175]. $\beta$-catenin interacts with AR and acts as a co-activator of AR to increase its transcriptional activity in response to androgen [17]. This leads to activation of AR target genes implicated in PCa progression. Therefore it is possible that n-3 PUFA can inhibit aberrant expression and activation of AR. As $\beta$-catenin is considered to be a ligand-dependent coactivator of AR transcription [17], the effects of n-3 PUFA on AR expression and $\beta$-catenin/ AR crosstalk is an area requiring exploration.

A series of experiments to specifically target different components of the $\mathrm{Wnt} / \beta$-catenin pathway as noted above would be a rational approach to determining the effects of $n-3$ PUFA in PCa. Goss's recent textbook reviews some innovative strategies that have been utilized to antagonize signaling at various levels of the Wnt/ $\beta$-catenin signaling [176]. These range from blocking $\beta$-catenin-mediated transcription to modulating the catenin destruction complex to attenuating extracellular signaling through the Wnt receptors [176]. Figure 2 illustrates the $\mathrm{Wnt} / \beta$-catenin pathway and could serve as a model to incorporate multiple targets of interest 


\begin{tabular}{|c|c|c|}
\hline Pathway Component & Alteration(s) & References \\
\hline \multicolumn{3}{|l|}{ A. Wnts } \\
\hline Wnt-1 & Increased Expression & [142] \\
\hline Wnt-2 & Increased Expression & {$[143,146,158]$} \\
\hline Wnt-5A & Increased Expression & {$[131,143,158]$} \\
\hline Wnt-6 & Increased Expression & {$[144]$} \\
\hline \multicolumn{3}{|c|}{ B. Secreted Wnt Antagonists } \\
\hline SFRP-1 & Decreased Expression & {$[148,149]$} \\
\hline SFRP-4 & Decreased Expression & {$[153,154]$} \\
\hline WIF-1 & Decreased Expression & [155] \\
\hline DKK-3 & Decreased Expression & {$[150-152]$} \\
\hline DKK-1 & Decreased Expression & {$[143,147]$} \\
\hline \multicolumn{3}{|c|}{ C. Wnt Receptors/coreceptors } \\
\hline FZD-3 & Increased Expression & {$[156]$} \\
\hline FZD-5 & Increased Expression & [159] \\
\hline \multicolumn{3}{|l|}{ D. Pathway Regulators } \\
\hline DVL-1 & Increased Expression & {$[141]$} \\
\hline \multicolumn{3}{|c|}{ E. Destruction Complex Components } \\
\hline$\beta$-catenin & Nucleus/cytoplasm accumulation & $\begin{array}{l}{[129-132,134,142,} \\
160-163]\end{array}$ \\
\hline APC & Decreased or Loss of Expression & $\begin{array}{l}{[132,134-137,139,} \\
140,164,165]\end{array}$ \\
\hline GSK-3 $\beta$ & Increased activity & {$[165-170]$} \\
\hline Axin-1 & Increased Expression & [138] \\
\hline \multicolumn{3}{|c|}{ F. Tcf/Lef Transcription Factor } \\
\hline Tcf-4 & Increased Expression & {$[142,171]$} \\
\hline \multicolumn{3}{|l|}{ F. Genes } \\
\hline CyclinD1 & Upregulation & {$[123,124]$} \\
\hline$c-m y c$ & Upregulation & {$[125-128,172-174]$} \\
\hline
\end{tabular}

Table 1. Components of the Wnt/ $\beta$-catenin Pathway Implicated in PCa: Alterations Of Primary PCa Tissues and PCa Cell Lines Compared to Normal Prostate. 
to be explored in n-3 PUFA and PCa. Therefore, research focusing on targeting components of the Wnt/ $\beta$-catenin pathway or other cellular pathways as a means of inhibiting PCa development and progression with a promising prospect, n-3 PUFA seems reasonable.

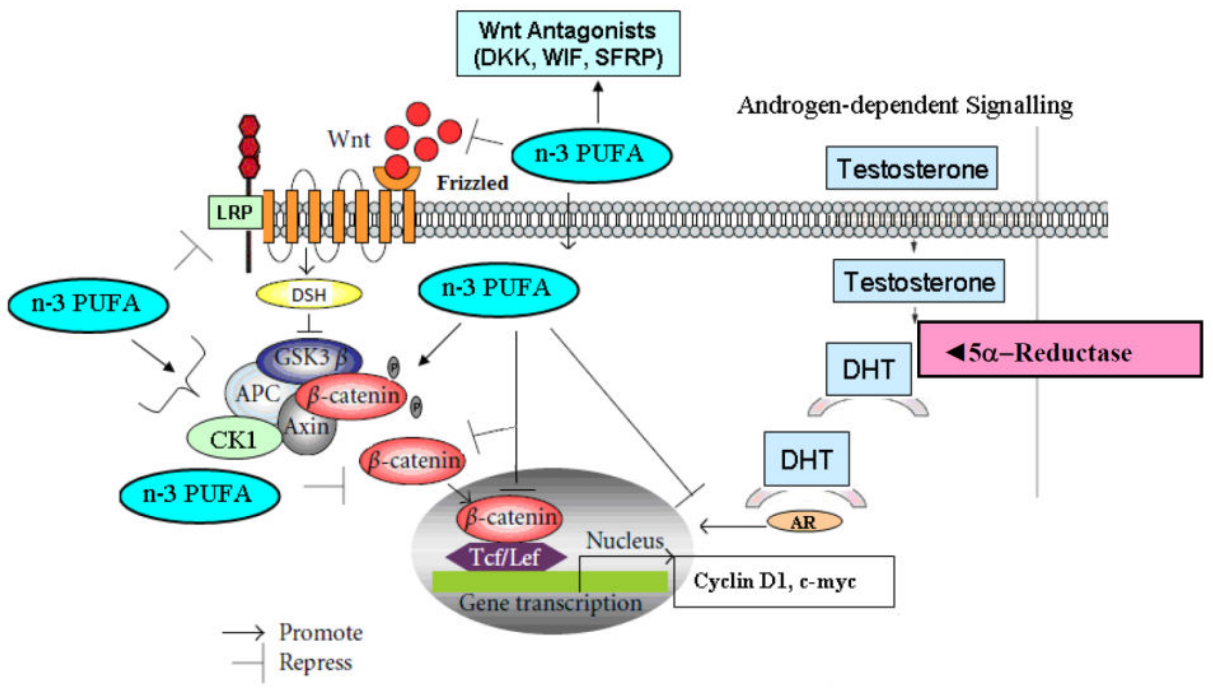

Figure 2. Tobin, GA. 2012. Adapted from articles under the Creative Commons Attribution License Copyright (c) 2011 Chi-Tai Yeh et al. [177] and from Lattouf et al. (Reprinted by permission from Macmillan Publishers Ltd: Nature Reviews Urology [178, 179]. Copyright (c) 1969). A hypothetical diagram of n-3 PUFA and n-3 PUFA/ androgen receptor induced inhibition of Wnt/B-catenin signaling pathway in PCa (directly and indirectly). When the Wnt signal is absent, a multi-complex destruction unit consisting of CK1/2, GSK3 $3, A P C$, and Axin forms the target for ubiquitination and degradation, namely a hyper-phosphorylated $\beta$-catenin. In the presence of Wnt, Fzd receptors recruit DVL to the plasma membrane to inactivate Axin. Overall, binding of Wnt ligand to a Frizzled/LRP receptor complex leads to stabilization of $\beta$-catenin. Subsequent interaction with nuclear Tcf/Lef proteins, increases the expression of genes such as cyclin D1 and c-myc. Additionally, as noted above the effects of n-3 PUFA on AR expression and $\beta$-catenin/AR crosstalk should be considered.

\section{Choosing a model: in vitro and in vivo prostate cancer models and their relevance to human disease}

Unpredictable pre-clinical models have been credited for the absence of effective treatments in Phase II and III trials [180, 181]. In fact, up to $70 \%$ attrition has been reported in Phase II trials; lack of efficacy accounts for about $30 \%$ of failures [180]. In the past, drug efficiency was normally assessed during the preclinical phase by xenografts of human prostate cancer cells. The limited number of cells lines that have been utilized in the past mostly include Prostate Cancer (PC)3, Lymph Node Carcinoma of the Prostate (LNCaP) and DU145 (DU-145). In vivo (ectopic or orthotopic xenograft models) and in vitro studies employing such remain at a disadvantage as these cells lack features found in chemically-induced cancers. The relevance 
of such models to human prostate cancer is debatable. Nonetheless, these models are valuable in initial research and preclinical assessments. While disease heterogeneity of prostate cancer continues to challenge the development of clinically relevant models, prostate cancer treatment approaches are reliant upon the development and incorporation of relevant preclinical models to confirm appropriate therapeutic targets and biomarkers. Perhaps the most significant milestone and best solution to date in providing researchers with a clinically relevant model, is the evolution of mouse models designed to intentionally inhibit or express a specific gene function by introducing foreign DNA. Over the past 15 years, these Genetically Engineered Mice (GEM) have become valuable tools in studying any combination of oncogenes expressed in specific tissues or conditionally through the tissue-specific removal of tumor suppressors [182-186]. The goal of GEM modeling is to render the best clinical and molecular characteristics of human cancer.

\subsection{Prostate cancer cell lines}

An exhaustive list of prostate cancer cell lines is freely available via the British Columbia Cancer Research Centre's Prostate Cancer Cell Line Database and Health Canada (website: http://capcellines.ca). This site was created to provide prostate cancer researchers with valuable information regarding cell lines to be utilized in their research. Information is available for 114 cell lines in total with information inclusive of origin, tumor forming ability in mice, doubling time (and other relevant growth factors), karyotype, as well as the status of ribonucleic acid (RNA) and protein for androgen receptor (AR), Prostate Specific Antigen (PSA), prostate-specific human kallikrein (hK2) and creatine kinase (CK). Prostate cancer xenograft models are also included as well as other relevant markers, too numerous to mention. This site conveniently includes cell lines deemed controversial in nature as well as those that have been reported as contaminated. It would seem that currently, and based on a recent search of PubMed, that the most widely used prostate cancer cell lines include PC-3, LNCaP and DU145.

Cell culture experiments provide a practical and financially viable means of investigating $\mathrm{PCa}$ research questions by providing preliminary and mechanistic data that justifies further research. Cell culture approaches do have limitations. In general, consider that the conditions represented in cell culture are artificial. The ideal concentrations of factors replicated to characterize the ideal environment are by no means representative of physiologic conditions. Combine this with the fact that cell culture experiments often utilize a single, clonally identical cell line of similar origin in identically constant conditions (i.e: flask culture). This is especially problematic in prostate cancer research due to the complexity of the interconnected paracrine and endocrine communications system between epithelium, stroma and endocrine organs (i.e: the pituitary) [52]. This use of a single cell type removes the ability to detect effects that a distant organ may have on the agent being tested. A co-culture in vitro model may prove to be a more reasonable approach. Additionally, the epithelial layer of the prostate is surrounded by a stromal layer containing fibrobasts and blood vessels, among other cell types. In cell culture models, communication of surrounding and distant tissues is not represented. In this manner, the effect of a therapeutic to surrounding and distant normal tissue is speculative. Further- 
more, cell culture represents only one end of the carcinogenic spectrum as it is often conducted on transformed cells. Aside from the ability of such cells to develop various escape / survival mechanisms, this concept negates long-term exposure. Throughout a person's lifespan, exposure to agents may have varying effects prior to, during or after the transformation process to neoplastic tissue.

Choosing an appropriate cell line is largely dependent on the type of study being conducted. For example, based on the model of study represented in this chapter, the LNCaP line would be an appropriate choice to study n-3 PUFA and $\beta$-catenin as these cells are androgen sensitive, prostate-specific antigen (PSA) positive, and maintain malignant properties, even though they have low metastatic potential [187]. Furthermore, this cell line endogenously expresses $\beta$ catenin [188] and thus represents an ideal tool to elucidate the interactions of n-3PUFA/ $\beta$ catenin in PCa.

\subsection{Animal models of prostate cancer}

Although animal experiments are both costly and time-consuming, they are vital in the transition to Phase 1 clinical investigations. As PCa occurs naturally both in dogs and in certain strains of rats, these species represent options for animal modeling [189]. Although the dog most closely resembles human PCa characteristics [190], their use is limited and unrealistic for a variety of reasons including androgen independent tumor growth, long latency period, prohibitive costs, long gestation period, and difficulty of genetic manipulation [189]. Some strains of rats, although well characterized and capable of developing a wide range of PCa phenotypes [191], present different issues including scarcity of tumors, variability in phenotypes, long latency periods, and inability to represent metastatic disease [189]. Utilization of genetically engineered rat models for PCa will likely increase as the development of knockout rats advance [192]. In the meantime, despite anatomical differences between the murine and human prostate gland [189] and other weaknesses, mouse models have emerged as the choice for investigating the stepwise progression of PCa. Compared to earlier in vivo prostate cancer experiments, where rodent models were exposed to carcinogens or hormones, recent technological advances (i.e.: tissue specific promoters and conditional gene deletions) have provided multiple models for researchers to investigate genetic defects [189]. Each model has its strengths and weaknesses. For example, the transgenic mouse models of PCa that express the Simian Virus 40 (SV40) early region have a highly prognostic gene signature for cancer, however mouse prostate expressing the large probasin promoter directed by SV40-large Tantigen (LPB-Tag) is not consistent in its ability to mimic the full spectrum of PCa as it only progresses to mPIN and rarely results in progression to adenocarcinoma formation [193]. Likely the most popular mouse model, TRAMP is based on such technology and develops cancer as a result of SV40 T antigen expression resulting in many genetic defects including p53 and $\mathrm{Rb}$ (tumor suppressor genes) loss [54]. Because cancer is not the result of a single genetic mutation, this multi-hit effect is desirable. However, consider that certain aspects of this model may not be relevant to human disease, including viral transformation. Additionally this model does not follow the normal human prostate cancer course as it is very aggressive and progresses to advanced cancer very rapidly. Consider that it may take up to 20 years for PIN to 
develop, 10 or more years to advance from PIN to HGPIN and then to an early form of latent cancer, while a clinical diagnosis of PCa may occur anywhere from three to 15 years [11].

It would be reiterative to include a thorough review of mouse models utilized in prostate cancer research following the publication of such excellent work by both Valkenburg et al. [189] and Hensley et al [194]. In this section we will summarize commonly utilized transgenic mouse models; later we will discuss the reliability of mouse models to study disease effects, specifically n-3 PUFA. Table 2 summarizes the characteristics of several commonly used transgeneic mouse models.

\begin{tabular}{|c|c|c|c|}
\hline Model & Genetic Manipulation & Characteristics & Reference \\
\hline Apt121/Rbf & $\begin{array}{l}\text { Fragment of SV } 40 \text { Transgene } \\
\text { to dominantly inactivate Rb }\end{array}$ & $\begin{array}{l}\text { PIN at age } 4 \text { weeks and micro-invasive } \\
\text { carcinoma at age } 8 \text { months. }\end{array}$ & [195] \\
\hline \multirow{2}{*}{$\begin{array}{l}\text { PTEN (Phosphatase and } \\
\text { tensin homologue } \\
\text { deleted on } \\
\text { chromosome 10) }\end{array}$} & Germline Knockout & $\begin{array}{l}\text { Invasive carcinoma age } 30 \text { weeks; } \\
\text { metastasis to lymph node and lung. }\end{array}$ & [196] \\
\hline & Conditional Knockout & $\begin{array}{l}\text { High grade PIN with advancement to } \\
\text { invasive metastasis. }\end{array}$ & {$[194]$} \\
\hline $\begin{array}{l}\text { Hi-Myc (high Myc } \\
\text { transgene expression) }\end{array}$ & Myc transgene Expression & $\begin{array}{l}\text { PIN at age } 2 \text { weeks and invasive } \\
\text { carcinoma at age } 6-12 \text { months with } \\
\text { lymphovascular invasion. }\end{array}$ & [197] \\
\hline $\begin{array}{l}\text { LADY (LPB promoter } \\
\text { driving the large-T } \\
\text { antigen) }\end{array}$ & SV40 Trangene Expression & $\begin{array}{l}\text { Neoplasis by age } 10 \text { weeks. } \\
\text { Undifferentiated adenocarcinoma and } \\
\text { invasive neuroendocrine tumors from } \\
\text { age } 5 \text { - } 9 \text { months and metastasis to } \\
\text { lymph node, liver and lung. }\end{array}$ & {$[194,198]$} \\
\hline Nkx3.1/Pten & $\begin{array}{l}\text { Compound Deletion (Pten(+/-) } \\
\text { Nkx3.1(-/-)) }\end{array}$ & $\begin{array}{l}\text { High-grade PIN at age } 6 \text { months; } \\
\text { invasion by age } 2 \text { months and } \\
\text { metastasis to lymph node. }\end{array}$ & {$[194,199]$} \\
\hline $\begin{array}{l}\text { TRAMP (TRansgenic } \\
\text { Adenocarcinoma of the } \\
\text { Mouse Prostate) }\end{array}$ & SV40 Transgene Expression & $\begin{array}{l}\text { Progressive PIN at age } 6 \text { weeks. } \\
\text { Invasive adenocarcinoma and lymph } \\
\text { node, liver, lung and skeletal } \\
\text { metastasis by age } 6 \text { months. Large, } \\
\text { poorly-differentiated neuroendocrine } \\
\text { tumors by age } 16 \text { weeks. }\end{array}$ & {$[182,194]$} \\
\hline
\end{tabular}

Table 2. Common Transgenic Murine Models of Prostate Cancer

In choosing a mouse model, one must consider whether the study is aimed at treatment or prevention and the ability of a model to produce prostate phenotypes or other key features 
relevant to human disease. In dietary intervention studies, such as n-3 PUFA, it is important to consider whether or not models are resistant to the tumor suppressive effects of such treatments. For example, Smolinski (2011) indicates that the TRAMP model may not be ideal for studying the effects of bioactive lipids on prostate carcinogenesis. In fact, in the context of a high fat diet, including fish oil and corn oil as the primary source of lipids, the TRAMP model is reported to be resistant to the tumor suppressive effects of n-3 PUFA [200]. Thus, choosing an inappropriate mouse model may negate significant findings and lead to the conclusion that certain dietary interventions have no effect on a disease when in fact they may be responsible for disease risk or progression. When engaging in novel or controversial research such as discussed in this chapter, a rational tactic before confirming a mouse model may include the completion of a pilot study to ensure that mice are not resistant to the protective effects of n-3 PUFA and to confirm an appropriate cohort size. The goal should be to identify at least a statistically significant $15 \%$ difference in mean tumor size within an $80 \%$ confidence interval. Based on the proposed research model discussed in this chapter, the transgenic 12T-7s/Catnb lox(ex3)/ PBCre4 (designated as LPB-Tag/DA $\beta$-catenin) mouse would likely be ideal and was developed recently as a model to study the expression of stabilized $\beta$-catenin in PCa and represents the full spectrum of PCa progression to invasive adenocarcinoma [169]. Additionally, this model represents AR activity and offers a reasonable study period, with an end-point of 20-22 weeks [169].

\section{6. n-3 PUFA specific factors that make a difference: Source, purity and EPA: DHA ratio}

If the general question on n-3 PUFA and PCa surrounds whether or not there is an increase or decrease in PCa cancer risk, then consideration of confounding factors for n-3 PUFA intake, including source, purity and ratio, should be addressed primarily. The foremost sources of essential fatty acids for the majority of studies are fish derived. Consider that both animal protein [201] and accumulated environmental pollutants [202] both have been linked to prostate cancer. In this regard, it is fitting that the development of n-3 PUFA as a pharmaceutical is already underway for other indications as the approval process normally removes the risk of contamination by methyl mercury, arsenic or other pollutants that are often seen in ocean or land based food sources protein [201]. Currently, there are three commercially significant formulations of pharmaceutical grade n-3 PUFAs and numerous over the counter supplements available for potential use in PCa. The noted differences between all of these formulas are purity, source and/or the ratio of EPA to DHA. Lovasa has received United States Food and Drug Administration (USFDA) approval to lower very high triglyceride levels (hypertriglyceridemia) [203]. In other major markets outside the United States, including Europe, Lovasa is known as Omacor, and can be prescribed to patients as a montherapy for hypertriglyceridemia, in combination therapy with a statin for mixed dyslipidemia, or as a secondary preventative therapeutic following myocardial infarction [204]. The expiration of GlaxoSmithKline's patent for Lovasa in September [2012] will likely increase availability of generic replacements. Such equally effective, but lower priced versions could supply markets 
for already proven indications as well as for subsequently approved disease indications, including for example, PCa. AMR-101, also marketed as Vascepa, received USFDA approval in July, 2012 [205]. Similar to Lovasa, this approval was based on effective treatment of hypertriglyceridemia but with the added ability to impact people with high triglycerides; the latter indication has been filed and is under review pending outcomes in clinical trials [206]. Epanova, another promising n-PUFA formula, is undergoing clinical trials for similar indications as previously mentioned for Lovasa, and USFDA approval is forthcoming [207]. Other dietary supplements, containing various amounts and ratios of n-3 PUFA which are sold over the counter in the United States and Canada would likely be based on values issued by the Institute of Medicine and National Academies as described below. Such unregulated formulary preparations do not undergo clinical trials. Studies relating to n-3 PUFA pharmaceutical preparations have focused on treating cardiovascular disease with no clinical consideration for PCa. Albeit, men diagnosed with PCa have accepted the use of such nutraceuticals and thus there is a role in ensuring that this approach constitutes safe and effective therapies. Although studies around the prescription formulas have demonstrated a very good safety and tolerability profile, the focus has been in treating cardiovascular disease and thus there has been no concern over potential adverse effects for other diseases.

Another proposed explanation for inconsistent findings in the role of n-3 PUFA in prostate cancer relates to absolute intake versus ratio of n-3 to n-6 PUFA. The latter may be more relevant for prostate cancer risk considering that the recommended dietary ratio of n-6/n-3 PUFA for health benefits are variable and range from 1:1-4:1, yet dietary intake in such studies, relative to the Western diet could contain 10 or more times the amount of n-6 compared to n-3 PUFA [208]. Also consider that in gathering and thoroughly reviewing all information toward this chapter, we were unable to find an official recommended daily allowance for n-3 PUFA for adults or children. In Canada and the United States, the general public and health professionals (including healthcare policy makers and public health officials) use a set of five nutrient based reference values issued by the Institute of Medicine and National Academies for a wide variety of food and dietary applications [209]. These dietary reference intakes (DRI), are inclusive of components including: estimated average requirements (EAR), recommended daily allowance (RDA), adequate intake (AI), tolerable upper intake level (UL) and an acceptable macronutrient distribution range (AMDR). Considered to be the official standard for federal agencies, these values are used to issue dietary guidance or policy directives for the health and well-being of individuals. In the absence of a DRI specific to EPA and DHA, the National Academies have recommended an AMDR of $10 \%$ for another n-3 PUFA, namely alpha-linolenic acid (ALA) to be consumed as EPA and/or DHA equating to a much lower value (about $100 \mathrm{mg} /$ day) than currently recommended by many groups worldwide. For example, a number of nutritionist and physicians recommend as much as 450 milligrams of n-3 PUFA in either DHA or EPA form per day to promote a healthy diet $[79,210]$, a fact alone which warrants further studies to determine DRI, specifically UL. More importantly, if the effects of n-3 PUFA represent different disease specifications, then it is crucial to establish DRIs for DHA and EPA individually, and in combination. Considering the contradictory evidence that excessive DHA may be a possible cause for some types of aggressive prostate cancer, the expansion of this field of research may want to revisit the incorporation of such basic factors as the ratio of EPA to DHA 
as a beginning to rationalize some existing data. Altogether, in proceeding with such studies, it would be important to consider all forms of n-3 PUFA, as well as a variety of ratios and then proper incorporation of such into cell-culture media or animal models; all while considering relevant study models to reflect relevance to human disease. However, while supplementation in cell based and animal studies may produce positive results, such may not be relevant to actual human therapies.

The existing results for n-3 PUFA and prostate are contradictory, especially in the absence of consistent epidemiological data. Therefore, incorporation of n-3 PUFA related factors such as source, purity and EPA/ DHA ratios are crucial while employing in vitro and in vivo models representative of the entire PCa cascade.

\section{Other considerations}

\subsection{Markers of tumor growth}

Epidemiologic studies have shown that lower serum insulin-like growth factor (IGF)-1 levels and increased IGF binding protein-3 (IGFBP-3) levels are associated with decreased PCa risk [211]. Unlike humans, rodents do not have a PSA counterpart for monitoring prostate cancer initiation and progression, however prostatic secretory protein (PSP)-94 has been established as a serum tumor marker [212]. However, measurement of mouse serum for IGF-I, IGFBP-3 and PSP-94 can be assayed using enzyme-linked immunosorbent assay (ELISA) using mousespecific antibodies and recombinant mouse standards (where applicable) and by methods previously described [213]. Therefore, such biomarkers could be used as indicators in both human and mouse studies in conjunction with other parameters and may be correlated with fatty acid analysis.

\subsection{Fatty acid analysis: Serum blood levels of EPA and DHA}

Selection of fatty acid concentration and methods of introducing fatty acids to cell cultures in such experiments are documented [214, 215]. Like most in vitro studies, data obtained may provide indicators of how to progress to the next levels of research. More relevant to human disease outcome, the fatty acid composition of serum (or plasma) phospholipid is an established valid biochemical marker for assessing the physiological status of various fatty acids including predictive correlations with the dietary intakes omega-3 PUFA, including EPA and DHA. [216, 217]. Serum fatty acid analysis by gas chromatography seems to be the standard for such experiments $[218,219]$ for both humans and animals.

\section{Conclusions}

As such, the features of prostate cancer, including long latency, high prevalence, significant mortality and morbidity, combined with the already accepted use of CAM, in particular n-3 
PUFA presents an excellent opportunity for nutritional intervention. However, until we unravel this controversial enigma of how n-3 PUFA affects prostate cancer, much remains to be explored and examined. More research is required to support or refute the value of n-3 PUFA in prostate cancer. And thus the search continues as to how one should proceed with fatty acid intake, including supplementation, as a prophylactic or therapeutic. Currently there is not enough evidence to discount the noted beneficial effects of n-3 PUFA intake to prevent heart disease as they seem to outweigh any harm related to prostate cancer risk [40]. However, further research is required to clarify the precise mechanisms of n-3 PUFA and its role in human disease, in particular cancer. Without such, we cannot develop novel strategies for n-3 PUFA to target molecular pathways (inflammatory or other involved processes) in the prevention, development or treatment of prostate cancer or other cancers. Expansion of research in this area is warranted.

\section{Acknowledgements}

Publication costs associated with this chapter were supported by the Department of Biomedical Sciences, University of Prince Edward Island, Canada. We are grateful for their continued support.

\section{Author details}

Gailene Tobin ${ }^{1}$, Robert Hurta ${ }^{2}$ and Marianna Kulka ${ }^{1,3}$

*Address all correspondence to: Marianna.Kulka@nrc-cnrc.gc.ca

1 Department of Biomedical Sciences, University of Prince Edward Island, Charlottetown, PE, Canada

2 Department of Biology, University of Prince Edward Island, Charlottetown, PE, Canada

3 Security and Disruptive Technologies / Technologies de sécurité et de rupture, National Institute of Nanotechnology, National Research Council Canada / Conseil national de recherches, Edmonton, AB, Canada

\section{References}

[1] Wasserman NF. Benign prostatic hyperplasia: a review and ultrasound classification. Radiol Clin North Am. 2006 Sept;44(5):689-710. PubMed PMID: 17030221. 
[2] Meyers RP. Structure of the Adult Prostate From a Clinician's Standpoint. Clinical Anatomy. 2000 June;13 214-15.

[3] Cohen RJ, Shannon BA, Phillips M, Moorin RE, Wheeler TM, Garrett KL. Central zone carcinoma of the prostate gland: a distinct tumor type with poor prognostic features. The Journal of Urology. 2008 May;179(5):1762-7; Discussion 7. PubMed PMID: 18343454.

[4] Anderson RU, Wise D, Sawyer T, Chan CA. Sexual dysfunction in men with chronic prostatitis/chronic pelvic pain syndrome: improvement after trigger point release and paradoxical relaxation training. The Journal of Urology. $2006 \mathrm{Oct} ; 176(4 \mathrm{Pt} 1)$ : 1534-8; discussion 8-9. PubMed PMID: 16952676.

[5] Verhamme KM, Dieleman JP, Bleumink GS, van der Lei J, Sturkenboom MC, Artibani $\mathrm{W}$, et al. Incidence and prevalence of lower urinary tract symptoms suggestive of benign prostatic hyperplasia in primary care--the Triumph project. European Urology. 2002 Oct;42(4):323-8. PubMed PMID: 12361895.

[6] Andriole GL, Crawford ED, Grubb RL, 3rd, Buys SS, Chia D, Church TR, et al. Mortality results from a randomized prostate-cancer screening trial. N Engl J Med. 2009 Mar 26;360(13):1310-9. PubMed PMID: 19297565.

[7] Boyle P, Brawley OW. Prostate cancer: current evidence weighs against population screening. CA Cancer J Clin. 2009 Jul-Aug;59(4):220-4. PubMed PMID: 19564244.

[8] Ross PL, Carroll, P. R., Small, E. J., et al. In Ko, A. H., Dollinger, M., \& Rosenbaum, E. . Everyone's Guide to Cancer Therapy: How Cancer is Diagnosed, Treated and Managed Day to Day. (5th Edition). Prostate. 2008. pp. 789-806. .

[9] Gleason DF. Histologic grade, clinical stage, and patient age in prostate cancer. NCI Monogr. 1988 (7):15-8. PubMed PMID: 3173500.

[10] Gleason DF. Histologic grading of prostate cancer: a perspective. Hum Pathol. 1992 Mar;23(3):273-9. PubMed PMID: 1555838.

[11] Bostwick DG. Prostatic intraepithelial neoplasia (PIN): current concepts. J Cell Biochem Suppl. 1992;16H:10-9. PubMed PMID: 1289664.

[12] Kelloff GJ, Lieberman R, Steele VE, Boone CW, Lubet RA, Kopelovitch L, et al. Chemoprevention of prostate cancer: concepts and strategies. European Urology. 1999;35(5-6):342-50. PubMed PMID: 10325487.

[13] DeVita VH, S; Rosenberg, SA. Principles and Practise of Oncology. 2005 (7th Edition): 1419-69.

[14] Kumar NB, Cantor A, Allen K, Riccardi D, Besterman-Dahan K, Seigne J, et al. The specific role of isoflavones in reducing prostate cancer risk. Prostate. 2004 May 1;59(2):141-7. PubMed PMID: 15042614. 
[15] Canadian Cancer Society. Canadian Cancer Encyclopedia. 2012. Available at: http:// info.cancer.ca/cce-ecc/.

[16] Hsing AW, Chokkalingam AP. Prostate cancer epidemiology. Front Biosci. 2006;11:1388-413. PubMed PMID: 16368524.

[17] Narizhneva NV, Tararova ND, Ryabokon P, Shyshynova I, Prokvolit A, Komarov PG, et al. Small molecule screening reveals a transcription-independent pro-survival function of androgen receptor in castration-resistant prostate cancer. Cell Cycle. 2009 Dec 15;8(24):4155-67. PubMed PMID: 19946220.

[18] Canadian Cancer Society. Prostate Cancer Statistics. 2011.

[19] Ferlay J, Shin HR, Bray F, Forman D, Mathers C, Parkin DM. Estimates of worldwide burden of cancer in 2008: GLOBOCAN 2008. Int J Cancer. 2010 Dec 15;127(12): 2893-917. PubMed PMID: 21351269.

[20] Jemal A, Siegel R, Xu J, Ward E. Cancer statistics, 2010. CA Cancer J Clin. 2010 SepOct;60(5):277-300. PubMed PMID: 20610543.

[21] Bubendorf L, Schopfer A, Wagner U, Sauter G, Moch H, Willi N, et al. Metastatic patterns of prostate cancer: an autopsy study of 1,589 patients. Hum Pathol. 2000 May; 31(5):578-83. PubMed PMID: 10836297.

[22] Lee RJ, Saylor PJ, Smith MR. Treatment and prevention of bone complications from prostate cancer. Bone. 2011 Jan;48(1):88-95. PubMed PMID: 20621630.

[23] Bray F, Moller B. Predicting the future burden of cancer. Nat Rev Cancer. 2006 Jan; 6(1):63-74. PubMed PMID: 16372017.

[24] Ferrari M. Cancer nanotechnology: opportunities and challenges. Nat Rev Cancer. 2005 Mar;5(3):161-71. PubMed PMID: 15738981.

[25] Scheinberg DA, Villa CH, Escorcia FE, McDevitt MR. Conscripts of the infinite armada: systemic cancer therapy using nanomaterials. Nat Rev Clin Oncol. 2010 May;7(5): 266-76. PubMed PMID: 20351700.

[26] Shewach DS, Kuchta RD. Introduction to cancer chemotherapeutics. Chem Rev. 2009 Jul;109(7):2859-61. PubMed PMID: 19583428.

[27] Chan JM, Gann PH, Giovannucci EL. Role of diet in prostate cancer development and progression. J Clin Oncol. 2005 Nov 10;23(32):8152-60. PubMed PMID: 16278466.

[28] Lee MM, Chang JS, Jacobs B, Wrensch MR. Complementary and alternative medicine use among men with prostate cancer in 4 ethnic populations. Am J Public Health. 2002 Oct;92(10):1606-9. PubMed PMID: 12356606.

[29] Nickel JS, D; Roehrborn,CG and Moyad, M. Nutraceuticals in Prostate Disease: The Urologist's Role. 2008. Summer (10(3):):192-206. 
[30] Armstrong B, Doll R. Environmental factors and cancer incidence and mortality in different countries, with special reference to dietary practices. Int J Cancer. 1975 Apr 15;15(4):617-31. PubMed PMID: 1140864.

[31] Mononen N, Schleutker J. Polymorphisms in genes involved in androgen pathways as risk factors for prostate cancer. The Journal of Urology. 2009 Apr;181(4):1541-9. PubMed PMID: 19230916.

[32] Odedina FT, Akinremi TO, Chinegwundoh F, Roberts R, Yu D, Reams RR, et al. Prostate cancer disparities in Black men of African descent: a comparative literature review of prostate cancer burden among Black men in the United States, Caribbean, United Kingdom, and West Africa. Infectious Agents and Cancer. 2009;4 Suppl 1:S2. PubMed PMID: 19208207.

[33] Patel AR, Klein EA. Risk factors for prostate cancer. Nature Clinical Practice Urology. 2009 Feb;6(2):87-95. PubMed PMID: 19198622.

[34] Cheung E, Wadhera P, Dorff T, Pinski J. Diet and prostate cancer risk reduction. Expert Rev Anticancer Ther. 2008 Jan;8(1):43-50. PubMed PMID: 18095882.

[35] Lippman SM, Hong WK. Cancer prevention science and practice. Cancer Res. 2002 Sep 15;62(18):5119-25. PubMed PMID: 12234971.

[36] William WN, Jr., Heymach JV, Kim ES, Lippman SM. Molecular targets for cancer chemoprevention. Nat Rev Drug Discov. 2009 Mar;8(3):213-25. PubMed PMID: 19247304.

[37] Huggins C, Hodges CV. Studies on prostatic cancer. I. The effect of castration, of estrogen and androgen injection on serum phosphatases in metastatic carcinoma of the prostate. CA Cancer J Clin. 1972 Jul-Aug;22(4):232-40. PubMed PMID: 4625049.

[38] Redman MW, Tangen CM, Goodman PJ, Lucia MS, Coltman CA, Jr., Thompson IM. Finasteride does not increase the risk of high-grade prostate cancer: a bias-adjusted modeling approach. Cancer Prev Res (Phila). 2008 Aug;1(3):174-81. PubMed PMID: 19138953.

[39] FDA Drug Safety Communication: 5-alpha reductase inhibitors (5-ARIs) may increase the risk of a more serious form of prostate cancer. 2011. Available at: http:// www.fda.gov/Drugs/DrugSafety/ucm258314.htm\#sa.

[40] Brasky TM, Till C, White E, Neuhouser ML, Song X, Goodman P, et al. Serum phospholipid fatty acids and prostate cancer risk: results from the prostate cancer prevention trial. Am J Epidemiol. 2011 Jun 15;173(12):1429-39. PubMed PMID: 21518693.

[41] Collette L, Studer UE, Schroder FH, Denis LJ, Sylvester RJ. Why phase III trials of maximal androgen blockade versus castration in M1 prostate cancer rarely show statistically significant differences. Prostate. 2001 Jun 15;48(1):29-39. PubMed PMID: 11391684. 
[42] Labrie F, Dupont A, Belanger A, St-Arnaud R, Giguere M, Lacourciere Y, et al. Treatment of prostate cancer with gonadotropin-releasing hormone agonists. Endocr Rev. 1986 Feb;7(1):67-74. PubMed PMID: 3514203.

[43] Visakorpi T, Hyytinen E, Koivisto P, Tanner M, Keinanen R, Palmberg C, et al. In vivo amplification of the androgen receptor gene and progression of human prostate cancer. Nat Genet. 1995 Apr;9(4):401-6. PubMed PMID: 7795646.

[44] Buchanan G, Greenberg NM, Scher HI, Harris JM, Marshall VR, Tilley WD. Collocation of androgen receptor gene mutations in prostate cancer. Clin Cancer Res. 2001 May;7(5):1273-81. PubMed PMID: 11350894.

[45] Culig Z, Hobisch A, Cronauer MV, Radmayr C, Trapman J, Hittmair A, et al. Androgen receptor activation in prostatic tumor cell lines by insulin-like growth factor-I, keratinocyte growth factor, and epidermal growth factor. Cancer Res. 1994 Oct 15;54(20):5474-8. PubMed PMID: 7522959.

[46] Bruckheimer EM, Brisbay S, Johnson DJ, Gingrich JR, Greenberg N, McDonnell TJ. Bcl-2 accelerates multistep prostate carcinogenesis in vivo. Oncogene. 2000 Nov 2;19(46):5251-8. PubMed PMID: 11077442.

[47] Trump DL, Havlin KH, Messing EM, Cummings KB, Lange PH, Jordan VC. Highdose ketoconazole in advanced hormone-refractory prostate cancer: endocrinologic and clinical effects. J Clin Oncol. 1989 Aug;7(8):1093-8. PubMed PMID: 2474059.

[48] Hanahan D, Weinberg RA. Hallmarks of cancer: the next generation. Cell. 2011. Mar 4;144(5):646-74. PubMed PMID: 21376230.

[49] de Muga S, Hernandez S, Agell L, Salido M, Juanpere N, Lorenzo M, et al. Molecular alterations of EGFR and PTEN in prostate cancer: association with high-grade and advanced-stage carcinomas. Mod Pathol. 2010 May;23(5):703-12. PubMed PMID: 20208477.

[50] Kawada M, Inoue H, Masuda T, Ikeda D. Insulin-like growth factor I secreted from prostate stromal cells mediates tumor-stromal cell interactions of prostate cancer. Cancer Res. 2006 Apr 15;66(8):4419-25. PubMed PMID: 16618768.

[51] Mendoza N, Phillips GL, Silva J, Schwall R, Wickramasinghe D. Inhibition of ligandmediated HER2 activation in androgen-independent prostate cancer. Cancer Res. 2002 Oct 1;62(19):5485-8. PubMed PMID: 12359757.

[52] Rakoff-Nahoum S. Why cancer and inflammation? The Yale Journal of Biology and Medicine. 2006 Dec;79(3-4):123-30. PubMed PMID: 17940622. Pubmed Central PMCID: 1994795.

[53] Chang WY, Birch L, Woodham C, Gold LI, Prins GS. Neonatal estrogen exposure alters the transforming growth factor-beta signaling system in the developing rat prostate and blocks the transient p21(cip1/waf1) expression associated with epithelial differentiation. Endocrinology. 1999 Jun;140(6):2801-13. PubMed PMID: 10342871. 
[54] Wiman KG. The retinoblastoma gene: role in cell cycle control and cell differentiation. Faseb J. 1993 Jul;7(10):841-5. PubMed PMID: 8393817.

[55] Brooks JD, Bova GS, Isaacs WB. Allelic loss of the retinoblastoma gene in primary human prostatic adenocarcinomas. Prostate. 1995 Jan;26(1):35-9. PubMed PMID: 7845865.

[56] Zhang W, Kapusta LR, Slingerland JM, Klotz LH. Telomerase activity in prostate cancer, prostatic intraepithelial neoplasia, and benign prostatic epithelium. Cancer Res. 1998 Feb 15;58(4):619-21. PubMed PMID: 9485010.

[57] Parangi S, O'Reilly M, Christofori G, Holmgren L, Grosfeld J, Folkman J, et al. Antiangiogenic therapy of transgenic mice impairs de novo tumor growth. Proc Natl Acad Sci U S A. 1996 Mar 5;93(5):2002-7. PubMed PMID: 8700875.

[58] Walsh K, Sriprasad S, Hopster D, Codd J, Mulvin D. Distribution of vascular endothelial growth factor (VEGF) in prostate disease. Prostate Cancer Prostatic Dis. 2002;5(2):119-22. PubMed PMID: 12497000.

[59] Wheelock MJ, Shintani Y, Maeda M, Fukumoto Y, Johnson KR. Cadherin switching. J Cell Sci. 2008 Mar 15;121(Pt 6):727-35. PubMed PMID: 18322269.

[60] Takeichi M. Morphogenetic roles of classic cadherins. Curr Opin Cell Biol. 1995 Oct; 7(5):619-27. PubMed PMID: 8573335.

[61] Tomita K, van Bokhoven A, van Leenders GJ, Ruijter ET, Jansen CF, Bussemakers MJ, et al. Cadherin switching in human prostate cancer progression. Cancer Res. 2000 Jul 1;60(13):3650-4. PubMed PMID: 10910081.

[62] Trudel D, Fradet Y, Meyer F, Harel F, Tetu B. Significance of MMP-2 expression in prostate cancer: an immunohistochemical study. Cancer Res. 2003 Dec 1;63(23): 8511-5. PubMed PMID: 14679018.

[63] Balkwill F, Mantovani A. Inflammation and cancer: back to Virchow? Lancet. 2001 Feb 17;357(9255):539-45. PubMed PMID: 11229684.

[64] Coussens LM, Werb Z. Inflammation and cancer. Nature. 2002 Dec 19-26;420(6917): 860-7. PubMed PMID: 12490959.

[65] De Marzo AM, Platz EA, Sutcliffe S, Xu J, Gronberg H, Drake CG, et al. Inflammation in prostate carcinogenesis. Nat Rev Cancer. 2007 Apr;7(4):256-69. PubMed PMID: 17384581 .

[66] Sfanos KS, De Marzo AM. Prostate cancer and inflammation: the evidence. Histopathology. 2012 Jan;60(1):199-215. PubMed PMID: 22212087.

[67] Condeelis J, Pollard JW. Macrophages: obligate partners for tumor cell migration, invasion, and metastasis. Cell. 2006 Jan 27;124(2):263-6. PubMed PMID: 16439202. 
[68] Egeblad M, Littlepage LE, Werb Z. The fibroblastic coconspirator in cancer progression. Cold Spring Harb Symp Quant Biol. 2005;70:383-8. PubMed PMID: 16869775.

[69] Egeblad M, Werb Z. New functions for the matrix metalloproteinases in cancer progression. Nat Rev Cancer. 2002 Mar;2(3):161-74. PubMed PMID: 11990853.

[70] Karin M. NF-kappaB as a critical link between inflammation and cancer. Cold Spring Harb Perspect Biol. 2009 Nov;1(5):141. PubMed PMID: 20066113.

[71] Wang D, Dubois RN. Prostaglandins and cancer. Gut. 2006 Jan;55(1):115-22. PubMed PMID: 16118353.

[72] Zlotnik A. Chemokines and cancer. Int J Cancer. 2006 Nov 1;119(9):2026-9. PubMed PMID: 16671092.

[73] Hadley CW, Clinton SK, Schwartz SJ. The consumption of processed tomato products enhances plasma lycopene concentrations in association with a reduced lipoprotein sensitivity to oxidative damage. J Nutr. 2003 Mar;133(3):727-32. PubMed PMID: 12612144 .

[74] Hsu A, Bray TM, Ho E. Anti-inflammatory activity of soy and tea in prostate cancer prevention. Exp Biol Med (Maywood). Jun;235(6):659-67. PubMed PMID: 20511670.

[75] Hsu A, Bruno RS, Lohr CV, Taylor AW, Dashwood RH, Bray TM, et al. Dietary soy and tea mitigate chronic inflammation and prostate cancer via NFkappaB pathway in the Noble rat model. J Nutr Biochem. May;22(5):502-10. PubMed PMID: 20801632.

[76] Pannellini T, Iezzi M, Liberatore M, Sabatini F, Iacobelli S, Rossi C, et al. A dietary tomato supplement prevents prostate cancer in TRAMP mice. Cancer Prev Res (Phila). Oct;3(10):1284-91. PubMed PMID: 20716635.

[77] Vardi A, Bosviel R, Rabiau N, Adjakly M, Satih S, Dechelotte P, et al. Soy phytoestrogens modify DNA methylation of GSTP1, RASSF1A, EPH2 and BRCA1 promoter in prostate cancer cells. In Vivo. Jul-Aug;24(4):393-400. PubMed PMID: 20668305.

[78] Astorg P. Dietary N-6 and N-3 polyunsaturated fatty acids and prostate cancer risk: a review of epidemiological and experimental evidence. Cancer Causes Control. 2004 May;15(4):367-86. PubMed PMID: 15141138.

[79] Astorg P, Arnault N, Czernichow S, Noisette N, Galan P, Hercberg S. Dietary intakes and food sources of n-6 and n-3 PUFA in French adult men and women. Lipids. 2004 Jun;39(6):527-35. PubMed PMID: 15554151.

[80] Chung BH, Mitchell SH, Zhang JS, Young CY. Effects of docosahexaenoic acid and eicosapentaenoic acid on androgen-mediated cell growth and gene expression in LNCaP prostate cancer cells. Carcinogenesis. 2001 Aug;22(8):1201-6. PubMed PMID: 11470750 . 
[81] Karmali RA, Reichel P, Cohen LA, Terano T, Hirai A, Tamura Y, et al. The effects of dietary omega-3 fatty acids on the DU-145 transplantable human prostatic tumor. Anticancer Res. 1987 Nov-Dec;7(6):1173-9. PubMed PMID: 2831791.

[82] Narayanan NK, Narayanan BA, Reddy BS. A combination of docosahexaenoic acid and celecoxib prevents prostate cancer cell growth in vitro and is associated with modulation of nuclear factor-kappaB, and steroid hormone receptors. Int J Oncol. 2005 Mar;26(3):785-92. PubMed PMID: 15703837.

[83] Pandalai PK, Pilat MJ, Yamazaki K, Naik H, Pienta KJ. The effects of omega-3 and omega-6 fatty acids on in vitro prostate cancer growth. Anticancer Res. 1996 MarApr;16(2):815-20. PubMed PMID: 8687134.

[84] Rose DP, Cohen LA. Effects of dietary menhaden oil and retinyl acetate on the growth of DU 145 human prostatic adenocarcinoma cells transplanted into athymic nude mice. Carcinogenesis. 1988 Apr;9(4):603-5. PubMed PMID: 3356068.

[85] Rose DP, Connolly JM. Effects of fatty acids and eicosanoid synthesis inhibitors on the growth of two human prostate cancer cell lines. Prostate. 1991;18(3):243-54. PubMed PMID: 2020620.

[86] Chavarro JE, Stampfer MJ, Li H, Campos H, Kurth T, Ma J. A prospective study of polyunsaturated fatty acid levels in blood and prostate cancer risk. Cancer Epidemiol Biomarkers Prev. 2007 Jul;16(7):1364-70. PubMed PMID: 17585059.

[87] Ghadirian P, Lacroix A, Maisonneuve P, Perret C, Drouin G, Perrault JP, et al. Nutritional factors and prostate cancer: a case-control study of French Canadians in Montreal, Canada. Cancer Causes Control. 1996 Jul;7(4):428-36. PubMed PMID: 8813431.

[88] Godley PA, Campbell MK, Miller C, Gallagher P, Martinson FE, Mohler JL, et al. Correlation between biomarkers of omega-3 fatty acid consumption and questionnaire data in African American and Caucasian United States males with and without prostatic carcinoma. Cancer Epidemiol Biomarkers Prev. 1996 Feb;5(2):115-9. PubMed PMID: 8850272.

[89] Kristal AR, Arnold KB, Neuhouser ML, Goodman P, Platz EA, Albanes D, et al. Diet, supplement use, and prostate cancer risk: results from the prostate cancer prevention trial. Am J Epidemiol. 2010 Sep 1;172(5):566-77. PubMed PMID: 20693267.

[90] Park SY, Wilkens LR, Henning SM, Le Marchand L, Gao K, Goodman MT, et al. Circulating fatty acids and prostate cancer risk in a nested case-control study: the Multiethnic Cohort. Cancer Causes Control. 2009 Mar;20(2):211-23. PubMed PMID: 18821021.

[91] Rohan TE, Howe GR, Burch JD, Jain M. Dietary factors and risk of prostate cancer: a case-control study in Ontario, Canada. Cancer Causes Control. 1995 Mar;6(2):145-54. PubMed PMID: 7749054.

[92] Terry PD, Rohan TE, Wolk A. Intakes of fish and marine fatty acids and the risks of cancers of the breast and prostate and of other hormone-related cancers: a review of 
the epidemiologic evidence. Am J Clin Nutr. 2003 Mar;77(3):532-43. PubMed PMID: 12600840 .

[93] Berquin IM, Min Y, Wu R, Wu J, Perry D, Cline JM, et al. Modulation of prostate cancer genetic risk by omega-3 and omega- 6 fatty acids. The Journal of Clinical Investigation. 2007 Jul;117(7):1866-75. PubMed PMID: 17607361.

[94] Hu Y, Sun H, Owens RT, Gu Z, Wu J, Chen YQ, et al. Syndecan-1-dependent suppression of PDK1/Akt/bad signaling by docosahexaenoic acid induces apoptosis in prostate cancer. Neoplasia. 2011 Oct;12(10):826-36. PubMed PMID: 20927321.

[95] Kelavkar UP, Hutzley J, Dhir R, Kim P, Allen KG, McHugh K. Prostate tumor growth and recurrence can be modulated by the omega-6:omega-3 ratio in diet: athymic mouse xenograft model simulating radical prostatectomy. Neoplasia. 2006 Feb;8(2): 112-24. PubMed PMID: 16611404.

[96] Vissapragada S, Ghosh A, Ringer L, Salinas P, Brophy A, Peaceman D, et al. Dietary n-3 polyunsaturated fatty acids fail to reduce prostate tumorigenesis in the PBErbB-2 x Pten(+/-) preclinical mouse model. Cell Cycle. 2010 May;9(9):1824-9. PubMed PMID: 20404514.

[97] Aronson WJ, Barnard RJ, Freedland SJ, Henning S, Elashoff D, Jardack PM, et al. Growth inhibitory effect of low fat diet on prostate cancer cells: results of a prospective, randomized dietary intervention trial in men with prostate cancer. The Journal of Urology. 2010 Jan;183(1):345-50. PubMed PMID: 19914662.

[98] Bureyko T, Hurdle H, Metcalfe JB, Clandinin MT, Mazurak VC. Reduced growth and integrin expression of prostate cells cultured with lycopene, vitamin $\mathrm{E}$ and fish oil in vitro. Br J Nutr. 2009 Apr;101(7):990-7. PubMed PMID: 18718045.

[99] Cavazos DA, Price RS, Apte SS, deGraffenried LA. Docosahexaenoic acid selectively induces human prostate cancer cell sensitivity to oxidative stress through modulation of NF-kappaB. Prostate. 2011 Sep 15;71(13):1420-8. PubMed PMID: 21360560.

[100] Istfan NW, Person KS, Holick MF, Chen TC. 1alpha,25-Dihydroxyvitamin D and fish oil synergistically inhibit G1/S-phase transition in prostate cancer cells. J Steroid Biochem Mol Biol. 2007 Mar;103(3-5):726-30. PubMed PMID: 17223546.

[101] Nakajima T, Kubota N, Tsutsumi T, Oguri A, Imuta H, Jo T, et al. Eicosapentaenoic acid inhibits voltage-gated sodium channels and invasiveness in prostate cancer cells. Br J Pharmacol. 2009 Feb;156(3):420-31. PubMed PMID: 19154441.

[102] Yi L, Zhang QY, Mi MT, Zheng, AI. Role of Rho GTPase in inhibiting metastatic ability of human prostate cancer cell line PC-3 by omega-3 polyunsaturated fatty acid. 2007 Dec;26(12):1281-6. PubMed PMID: 18076787.

[103] Fradet V, Cheng I, Casey G, Witte JS. Dietary omega-3 fatty acids, cyclooxygenase-2 genetic variation, and aggressive prostate cancer risk. Clinical Cancer Research. 2009 Apr 1;15(7):2559-66. PubMed PMID: 19318492. 
[104] Chang HY, Sneddon JB, Alizadeh AA, Sood R, West RB, Montgomery K, et al. Gene expression signature of fibroblast serum response predicts human cancer progression: similarities between tumors and wounds. PLoS Biol. 2004 Feb;2(2):E7. PubMed PMID: 14737219.

[105] Woodward K. A high percentage of omega-3 fatty acids in the blood is linked to an increased risk of aggressive prostate cancer. 2011. Available at: wwwfhcrc.org.

[106] Beachy PA, Karhadkar SS, Berman DM. Tissue repair and stem cell renewal in carcinogenesis. Nature. 2004 Nov 18;432(7015):324-31. PubMed PMID: 15549094.

[107] Friedrichs W, Ruparel SB, Marciniak RA, DeGraffenried L. Omega-3 fatty acid inhibition of prostate cancer progression to hormone independence is associated with suppression of mTOR signaling and androgen receptor expression. Nutrition and Cancer. 2010;63(5):771-7. PubMed PMID: 21667400.

[108] Lim K, Han C, Dai Y, Shen M, Wu T. Omega-3 polyunsaturated fatty acids inhibit hepatocellular carcinoma cell growth through blocking beta-catenin and cyclooxygenase-2. Mol Cancer Ther. 2009 Nov;8(11):3046-55. PubMed PMID: 19887546.

[109] Lim K, Han C, Xu L, Isse K, Demetris AJ, Wu T. Cyclooxygenase-2-derived prostaglandin E2 activates beta-catenin in human cholangiocarcinoma cells: evidence for inhibition of these signaling pathways by omega 3 polyunsaturated fatty acids. Cancer Res. 2008 Jan 15;68(2):553-60. PubMed PMID: 18199552.

[110] Calviello G, Resci F, Serini S, Piccioni E, Toesca A, Boninsegna A, et al. Docosahexaenoic acid induces proteasome-dependent degradation of beta-catenin, down-regulation of survivin and apoptosis in human colorectal cancer cells not expressing COX-2. Carcinogenesis. 2007 Jun;28(6):1202-9. PubMed PMID: 17183061.

[111] Calviello G, Serini S, Piccioni E. n-3 polyunsaturated fatty acids and the prevention of colorectal cancer: molecular mechanisms involved. Curr Med Chem. 2007;14(29): 3059-69. PubMed PMID: 18220742.

[112] Narayanan BA, Narayanan NK, Desai D, Pittman B, Reddy BS. Effects of a combination of docosahexaenoic acid and 1,4-phenylene bis(methylene) selenocyanate on cyclooxygenase 2, inducible nitric oxide synthase and beta-catenin pathways in colon cancer cells. Carcinogenesis. 2004 Dec;25(12):2443-9. PubMed PMID: 15297372.

[113] Lu Y, Nie D, Witt WT, Chen Q, Shen M, Xie H, et al. Expression of the fat-1 gene diminishes prostate cancer growth in vivo through enhancing apoptosis and inhibiting GSK-3 beta phosphorylation. Mol Cancer Ther. 2008 Oct;7(10):3203-11. PubMed PMID: 18852124.

[114] Miller JR. The Wnts. Genome Biol. 2002;3(1):REVIEWS3001. PubMed PMID: 11806834.

[115] MacDonald BT, Tamai K, He X. Wnt/beta-catenin signaling: components, mechanisms, and diseases. Dev Cell. 2009 Jul;17(1):9-26. PubMed PMID: 19619488. 
[116] Clevers H. Wnt/beta-catenin signaling in development and disease. Cell. 2006 Nov 3;127(3):469-80. PubMed PMID: 17081971.

[117] Gordon MD, Nusse R. Wnt signaling: multiple pathways, multiple receptors, and multiple transcription factors. J Biol Chem. 2006 Aug 11;281(32):22429-33. PubMed PMID: 16793760.

[118] Bandapalli OR, Dihlmann S, Helwa R, Macher-Goeppinger S, Weitz J, Schirmacher P, et al. Transcriptional activation of the beta-catenin gene at the invasion front of colorectal liver metastases. J Pathol. 2009 Jul;218(3):370-9. PubMed PMID: 19347947.

[119] Hoppler S, Kavanagh CL. Wnt signalling: variety at the core. J Cell Sci. 2007 Feb 1;120(Pt 3):385-93. PubMed PMID: 17251379.

[120] Moon RT, Kohn AD, De Ferrari GV, Kaykas A. WNT and beta-catenin signalling: diseases and therapies. Nat Rev Genet. 2004 Sep;5(9):691-701. PubMed PMID: 15372092.

[121] Terry S, Yang X, Chen MW, Vacherot F, Buttyan R. Multifaceted interaction between the androgen and Wnt signaling pathways and the implication for prostate cancer. J Cell Biochem. 2006 Oct 1;99(2):402-10. PubMed PMID: 16741972.

[122] Tetsu O, McCormick F. Beta-catenin regulates expression of cyclin D1 in colon carcinoma cells. Nature. 1999 Apr 1;398(6726):422-6. PubMed PMID: 10201372.

[123] Comstock CE, Revelo MP, Buncher CR, Knudsen KE. Impact of differential cyclin D1 expression and localisation in prostate cancer. Br J Cancer. 2007 Mar 26;96(6):970-9. PubMed PMID: 17375037.

[124] Drobnjak M, Osman I, Scher HI, Fazzari M, Cordon-Cardo C. Overexpression of cyclin D1 is associated with metastatic prostate cancer to bone. Clinical Cancer Research. 2000 May;6(5):1891-5. PubMed PMID: 10815912.

[125] Fleming WH, Hamel A, MacDonald R, Ramsey E, Pettigrew NM, Johnston B, et al. Expression of the c-myc protooncogene in human prostatic carcinoma and benign prostatic hyperplasia. Cancer Res. 1986 Mar;46(3):1535-8. PubMed PMID: 2417706.

[126] Jenkins RB, Qian J, Lieber MM, Bostwick DG. Detection of c-myc oncogene amplification and chromosomal anomalies in metastatic prostatic carcinoma by fluorescence in situ hybridization. Cancer Res. 1997 Feb 1;57(3):524-31. PubMed PMID: 9012485.

[127] Qian J, Hirasawa K, Bostwick DG, Bergstralh EJ, Slezak JM, Anderl KL, et al. Loss of p53 and c-myc overrepresentation in stage $\mathrm{T}(2-3) \mathrm{N}(1-3) \mathrm{M}(0)$ prostate cancer are potential markers for cancer progression. Mod Pathol. 2002 Jan;15(1):35-44. PubMed PMID: 11796839.

[128] Sato H, Minei S, Hachiya T, Yoshida T, Takimoto Y. Fluorescence in situ hybridization analysis of c-myc amplification in stage TNM prostate cancer in Japanese patients. Int J Urol. 2006 Jun;13(6):761-6. PubMed PMID: 16834657. 
[129] Chesire DR, Ewing CM, Sauvageot J, Bova GS, Isaacs WB. Detection and analysis of beta-catenin mutations in prostate cancer. Prostate. 2000 Dec 1;45(4):323-34. PubMed PMID: 11102958.

[130] de la Taille A, Rubin MA, Chen MW, Vacherot F, de Medina SG, Burchardt M, et al. Beta-catenin-related anomalies in apoptosis-resistant and hormone-refractory prostate cancer cells. Clinical Cancer Research. 2003 May;9(5):1801-7. PubMed PMID: 12738737.

[131] Yamamoto H, Oue N, Sato A, Hasegawa Y, Yamamoto H, Matsubara A, et al. Wnt5a signaling is involved in the aggressiveness of prostate cancer and expression of metalloproteinase. Oncogene. Apr 8;29(14):2036-46. PubMed PMID: 20101234.

[132] Gerstein AV, Almeida TA, Zhao G, Chess E, Shih Ie M, Buhler K, et al. APC/CTNNB1 (beta-catenin) pathway alterations in human prostate cancers. Genes Chromosomes Cancer. 2002 May;34(1):9-16. PubMed PMID: 11921277.

[133] Chesire DR, Ewing CM, Gage WR, Isaacs WB. In vitro evidence for complex modes of nuclear beta-catenin signaling during prostate growth and tumorigenesis. Oncogene. 2002 Apr 18;21(17):2679-94. PubMed PMID: 11965541.

[134] Yardy GW, Brewster SF. Wnt signalling and prostate cancer. Prostate Cancer Prostatic Dis. 2005;8(2):119-26. PubMed PMID: 15809669.

[135] Henrique R, Ribeiro FR, Fonseca D, Hoque MO, Carvalho AL, Costa VL, et al. High promoter methylation levels of APC predict poor prognosis in sextant biopsies from prostate cancer patients. Clinical Cancer Research. 2007 Oct 15;13(20):6122-9. PubMed PMID: 17947477.

[136] Brewster SF, Kemple T, MacIver AG, Astley JP, Gingell JC. The Bristol prostate cancer pilot screening study: a 3-year follow-up. Br J Urol. 1994 Nov;74(5):556-8. PubMed PMID: 7530117.

[137] Phillips SM, Barton CM, Lee SJ, Morton DG, Wallace DM, Lemoine NR, et al. Loss of the retinoblastoma susceptibility gene (RB1) is a frequent and early event in prostatic tumorigenesis. Br J Cancer. 1994 Dec;70(6):1252-7. PubMed PMID: 7526887.

[138] Yardy GW, Bicknell DC, Wilding JL, Bartlett S, Liu Y, Winney B, et al. Mutations in the AXIN1 gene in advanced prostate cancer. European Urology. 2009 Sep;56(3): 486-94. PubMed PMID: 18514389.

[139] Bastian PJ, Ellinger J, Wellmann A, Wernert N, Heukamp LC, Muller SC, et al. Diagnostic and prognostic information in prostate cancer with the help of a small set of hypermethylated gene loci. Clinical Cancer Research. 2005 Jun 1;11(11):4097-106. PubMed PMID: 15930345.

[140] Jeronimo C, Henrique R, Hoque MO, Mambo E, Ribeiro FR, Varzim G, et al. A quantitative promoter methylation profile of prostate cancer. Clinical Cancer Research. 2004 Dec 15;10(24):8472-8. PubMed PMID: 15623627. 
[141] Mizutani K, Miyamoto S, Nagahata T, Konishi N, Emi M, Onda M. Upregulation and overexpression of DVL1, the human counterpart of the Drosophila dishevelled gene, in prostate cancer. Tumori. 2005 Nov-Dec;91(6):546-51. PubMed PMID: 16457155.

[142] Chen G, Shukeir N, Potti A, Sircar K, Aprikian A, Goltzman D, et al. Up-regulation of Wnt-1 and beta-catenin production in patients with advanced metastatic prostate carcinoma: potential pathogenetic and prognostic implications. Cancer. 2004 Sep 15;101(6):1345-56. PubMed PMID: 15316903.

[143] Hall CL, Bafico A, Dai J, Aaronson SA, Keller ET. Prostate cancer cells promote osteoblastic bone metastases through Wnts. Cancer Res. 2005 Sep 1;65(17):7554-60. PubMed PMID: 16140917.

[144] Iozzo RV, Eichstetter I, Danielson KG. Aberrant expression of the growth factor Wnt-5A in human malignancy. Cancer Res. 1995 Aug 15;55(16):3495-9. PubMed PMID: 7627953.

[145] Wang Q, Symes AJ, Kane CA, Freeman A, Nariculam J, Munson P, et al. A novel role for Wnt/Ca2+ signaling in actin cytoskeleton remodeling and cell motility in prostate cancer. PLoS One. 2010;5(5):e10456. PubMed PMID: 20454608.

[146] Katoh M. Differential regulation of WNT2 and WNT2B expression in human cancer. Int J Mol Med. 2001 Dec;8(6):657-60. PubMed PMID: 11712082.

[147] Hall CL, Daignault SD, Shah RB, Pienta KJ, Keller ET. Dickkopf-1 expression increases early in prostate cancer development and decreases during progression from primary tumor to metastasis. Prostate. 2008 Sep 15;68(13):1396-404. PubMed PMID: 18561248.

[148] Coutinho-Camillo CM, Salaorni S, Sarkis AS, Nagai MA. Differentially expressed genes in the prostate cancer cell line LNCaP after exposure to androgen and anti-androgen. Cancer Genet Cytogenet. 2006 Apr 15;166(2):130-8. PubMed PMID: 16631469.

[149] Kawano Y, Diez S, Uysal-Onganer P, Darrington RS, Waxman J, Kypta RM. Secreted Frizzled-related protein-1 is a negative regulator of androgen receptor activity in prostate cancer. Br J Cancer. 2009 Apr 7;100(7):1165-74. PubMed PMID: 19277043.

[150] Kawano Y, Kitaoka M, Hamada Y, Walker MM, Waxman J, Kypta RM. Regulation of prostate cell growth and morphogenesis by Dickkopf-3. Oncogene. 2006 Oct 19;25(49):6528-37. PubMed PMID: 16751809.

[151] Zenzmaier C, Untergasser G, Hermann M, Dirnhofer S, Sampson N, Berger P. Dysregulation of Dkk-3 expression in benign and malignant prostatic tissue. Prostate. 2008 Apr 1;68(5):540-7. PubMed PMID: 18247400.

[152] Lodygin D, Epanchintsev A, Menssen A, Diebold J, Hermeking H. Functional epigenomics identifies genes frequently silenced in prostate cancer. Cancer Res. 2005 May 15;65(10):4218-27. PubMed PMID: 15899813. 
[153] Horvath LG, Henshall SM, Kench JG, Saunders DN, Lee CS, Golovsky D, et al. Membranous expression of secreted frizzled-related protein 4 predicts for good prognosis in localized prostate cancer and inhibits PC3 cellular proliferation in vitro. Clinical Cancer Research. 2004 Jan 15;10(2):615-25. PubMed PMID: 14760084.

[154] Horvath LG, Lelliott JE, Kench JG, Lee CS, Williams ED, Saunders DN, et al. Secreted frizzled-related protein 4 inhibits proliferation and metastatic potential in prostate cancer. Prostate. 2007 Jul 1;67(10):1081-90. PubMed PMID: 17476687.

[155] Wissmann C, Wild PJ, Kaiser S, Roepcke S, Stoehr R, Woenckhaus M, et al. WIF1, a component of the Wnt pathway, is down-regulated in prostate, breast, lung, and bladder cancer. J Pathol. 2003 Oct;201(2):204-12. PubMed PMID: 14517837.

[156] Liss MA, Schlicht M, Kahler A, Fitzgerald R, Thomassi T, Degueme A, et al. Characterization of soy-based changes in Wnt-frizzled signaling in prostate cancer. Cancer Genomics Proteomics. 2011 Sep-Oct;7(5):245-52. PubMed PMID: 20952759.

[157] Thiele S, Rauner M, Goettsch C, Rachner TD, Benad P, Fuessel S, et al. Expression profile of WNT molecules in prostate cancer and its regulation by aminobisphosphonates. J Cell Biochem. 2011 Jun;112(6):1593-600. PubMed PMID: 21344486.

[158] Hall CL, Kang S, MacDougald OA, Keller ET. Role of Wnts in prostate cancer bone metastases. J Cell Biochem. 2006 Mar 1;97(4):661-72. PubMed PMID: 16447163.

[159] Thiele S, Rauner M, Goettsch C, Rachner TD, Benad P, Fuessel S, et al. Expression profile of WNT molecules in prostate cancer and its regulation by aminobisphosphonates. J Cell Biochem. Jun;112(6):1593-600. PubMed PMID: 21344486.

[160] Bierie B, Nozawa M, Renou JP, Shillingford JM, Morgan F, Oka T, et al. Activation of beta-catenin in prostate epithelium induces hyperplasias and squamous transdifferentiation. Oncogene. 2003 Jun 19;22(25):3875-87. PubMed PMID: 12813461.

[161] Lu W, Tinsley HN, Keeton A, Qu Z, Piazza GA, Li Y. Suppression of Wnt/beta-catenin signaling inhibits prostate cancer cell proliferation. Eur J Pharmacol. 2009 Jan 5;602(1):8-14. PubMed PMID: 19026633.

[162] Voeller HJ, Truica CI, Gelmann EP. Beta-catenin mutations in human prostate cancer. Cancer Res. 1998 Jun 15;58(12):2520-3. PubMed PMID: 9635571.

[163] Whitaker HC, Girling J, Warren AY, Leung H, Mills IG, Neal DE. Alterations in betacatenin expression and localization in prostate cancer. Prostate. 2008 Aug 1;68(11): 1196-205. PubMed PMID: 18459111.

[164] Bruxvoort KJ, Charbonneau HM, Giambernardi TA, Goolsby JC, Qian CN, Zylstra $\mathrm{CR}$, et al. Inactivation of Apc in the mouse prostate causes prostate carcinoma. Cancer Res. 2007 Mar 15;67(6):2490-6. PubMed PMID: 17363566.

[165] Davies G, Jiang WG, Mason MD. The interaction between beta-catenin, GSK3beta and APC after motogen induced cell-cell dissociation, and their involvement in sig- 
nal transduction pathways in prostate cancer. Int J Oncol. 2001 Apr;18(4):843-7. PubMed PMID: 11251183.

[166] Guertin DA, Stevens DM, Saitoh M, Kinkel S, Crosby K, Sheen JH, et al. mTOR complex 2 is required for the development of prostate cancer induced by Pten loss in mice. Cancer Cell. 2009 Feb 3;15(2):148-59. PubMed PMID: 19185849.

[167] Liao X, Zhang L, Thrasher JB, Du J, Li B. Glycogen synthase kinase-3beta suppression eliminates tumor necrosis factor-related apoptosis-inducing ligand resistance in prostate cancer. Mol Cancer Ther. 2003 Nov;2(11):1215-22. PubMed PMID: 14617795.

[168] Mazor M, Kawano Y, Zhu H, Waxman J, Kypta RM. Inhibition of glycogen synthase kinase-3 represses androgen receptor activity and prostate cancer cell growth. Oncogene. 2004 Oct 14;23(47):7882-92. PubMed PMID: 15361837.

[169] Yu X, Wang Y, DeGraff DJ, Wills ML, Matusik RJ. Wnt/beta-catenin activation promotes prostate tumor progression in a mouse model. Oncogene. 2010 Apr 21;30(16): 1868-79. PubMed PMID: 21151173.

[170] Zhu Q, Yang J, Han S, Liu J, Holzbeierlein J, Thrasher JB, et al. Suppression of glycogen synthase kinase 3 activity reduces tumor growth of prostate cancer in vivo. Prostate. 2010 Oct 28; 71(8):835-45. PubMed PMID: 21031441.

[171] Agalliu I, Suuriniemi M, Prokunina-Olsson L, Johanneson B, Collins FS, Stanford JL, et al. Evaluation of a variant in the transcription factor 7-like 2 (TCF7L2) gene and prostate cancer risk in a population-based study. Prostate. 2008 May 15;68(7):740-7. PubMed PMID: 18302196.

[172] Bubendorf L, Kononen J, Koivisto P, Schraml P, Moch H, Gasser TC, et al. Survey of gene amplifications during prostate cancer progression by high-throughout fluorescence in situ hybridization on tissue microarrays. Cancer Res. 1999 Feb 15;59(4):803-6. PubMed PMID: 10029066.

[173] Gurel B, Iwata T, Koh CM, Jenkins RB, Lan F, Van Dang C, et al. Nuclear MYC protein overexpression is an early alteration in human prostate carcinogenesis. Mod Pathol. 2008 Sep;21(9):1156-67. PubMed PMID: 18567993.

[174] Iversen PL, Arora V, Acker AJ, Mason DH, Devi GR. Efficacy of antisense morpholino oligomer targeted to c-myc in prostate cancer xenograft murine model and a Phase I safety study in humans. Clinical Cancer Research. 2003 Jul;9(7):2510-9. PubMed PMID: 12855625.

[175] Yu X, Wang Y, Jiang M, Bierie B, Roy-Burman P, Shen MM, et al. Activation of betaCatenin in mouse prostate causes HGPIN and continuous prostate growth after castration. Prostate. 2009 Feb 15;69(3):249-62. PubMed PMID: 18991257.

[176] Goss, KH. and Kahn, M. Targeting the Wnt Pathway in Cancer. Springer. 2011. ISBN-10: 1441980229. 
[177] Yeh CT, Yao CJ, Yan JL, Chuang SE, Lee LM, Chen CM, et al. Apoptotic Cell Death and Inhibition of Wnt/beta-Catenin Signaling Pathway in Human Colon Cancer Cells by an Active Fraction (HS7) from Taiwanofungus camphoratus. Evid Based Complement Alternat Med. 2011. Article ID: 750230. PubMed PMID: 21423639.

[178] Lattouf J, Srinivasan R, Pinto PA, Linehan WM, Neckers L. Mechanisms of disease: the role of heat-shock protein 90 in genitourinary malignancy. Nature Clinical Practice Urology. 2006 Nov;3(11):590-601. PubMed PMID: 17088927.

[179] Lattouf J, Srinivanasan, R. Pinto, PA. Linehan, WM and Neckers, L. Mechanisms of Disease: the role of heat-shock protein 90 in genitourinary malignancy. Nature Reviews Urology. 1969 December 31; 3(11).

[180] Booth B, Glassman R, Ma P. Oncology's trials. Nat Rev Drug Discov. 2003 Aug;2(8): 609-10. PubMed PMID: 12908467.

[181] Kola I, Landis J. Can the pharmaceutical industry reduce attrition rates? Nat Rev Drug Discov. 2004 Aug;3(8):711-5. PubMed PMID: 15286737.

[182] Greenberg NM, DeMayo F, Finegold MJ, Medina D, Tilley WD, Aspinall JO, et al. Prostate cancer in a transgenic mouse. Proc Natl Acad Sci U S A. 1995 Apr 11;92(8): 3439-43. PubMed PMID: 7724580.

[183] Jeet V, Russell PJ, Khatri A. Modeling prostate cancer: a perspective on transgenic mouse models. Cancer Metastasis Rev. Mar;29(1):123-42. PubMed PMID: 20143131.

[184] Mimeault M, Batra SK. Animal models relevant to human prostate carcinogenesis underlining the critical implication of prostatic stem/progenitor cells. Biochim Biophys Acta. Aug;1816(1):25-37. PubMed PMID: 21396984.

[185] Navone NM, Logothetis CJ, von Eschenbach AC, Troncoso P. Model systems of prostate cancer: uses and limitations. Cancer Metastasis Rev. 1998;17(4):361-71. PubMed PMID: 10453280.

[186] van Weerden WM, Bangma C, de Wit R. Human xenograft models as useful tools to assess the potential of novel therapeutics in prostate cancer. Br J Cancer. 2009 Jan 13;100(1):13-8. PubMed PMID: 19088719.

[187] Horoszewicz JS, Leong SS, Kawinski E, Karr JP, Rosenthal H, Chu TM, et al. LNCaP model of human prostatic carcinoma. Cancer Res. 1983 Apr;43(4):1809-18. PubMed PMID: 6831420.

[188] Jiang YG, Zhao JH, Luo Y, He DL, Li N, Cui XH, et al. Expressions of E-cadherin and beta-catenin in $\mathrm{LNCaP}$ and $\mathrm{ARCaP}$ cell lines and their significance. Zhonghua Nan Ke Xue. 2009 Oct;15(10):867-71. PubMed PMID: 20112731.

[189] Valkenburg KC, Williams BO. Mouse models of prostate cancer. Prostate cancer. 2011;2011:895238. PubMed PMID: 22111002. Pubmed Central PMCID: 3221286. 
[190] Leroy BE, Northrup N. Prostate cancer in dogs: comparative and clinical aspects. Vet J. 2009 May;180(2):149-62. PubMed PMID: 18786842.

[191] Rosol TJ, Tannehill-Gregg SH, Corn S, Schneider A, McCauley LK. Animal models of bone metastasis. Cancer Treat Res. 2004;118:47-81. PubMed PMID: 15043188.

[192] Hamra FK. Gene targeting: Enter the rat. Nature. Sep 9;467(7312):161-3. PubMed PMID: 20829783.

[193] Deeb KK, Michalowska AM, Yoon CY, Krummey SM, Hoenerhoff MJ, Kavanaugh C, et al. Identification of an integrated SV40 T/t-antigen cancer signature in aggressive human breast, prostate, and lung carcinomas with poor prognosis. Cancer Res. 2007 Sep 1;67(17):8065-80. PubMed PMID: 17804718.

[194] Hensley PJ, Kyprianou N. Modeling prostate cancer in mice: limitations and opportunities. J Androl. 2011 Mar-Apr;33(2):133-44. PubMed PMID: 21680808.

[195] Hill R, Song Y, Cardiff RD, Van Dyke T. Heterogeneous tumor evolution initiated by loss of $\mathrm{pRb}$ function in a preclinical prostate cancer model. Cancer Res. 2005 Nov 15;65(22):10243-54. PubMed PMID: 16288012.

[196] Wang S, Gao J, Lei Q, Rozengurt N, Pritchard C, Jiao J, et al. Prostate-specific deletion of the murine Pten tumor suppressor gene leads to metastatic prostate cancer. Cancer Cell. 2003 Sep;4(3):209-21. PubMed PMID: 14522255.

[197] Ellwood-Yen K, Graeber TG, Wongvipat J, Iruela-Arispe ML, Zhang J, Matusik R, et al. Myc-driven murine prostate cancer shares molecular features with human prostate tumors. Cancer Cell. 2003 Sep;4(3):223-38. PubMed PMID: 14522256.

[198] Masumori N, Thomas TZ, Chaurand P, Case T, Paul M, Kasper S, et al. A probasinlarge $\mathrm{T}$ antigen transgenic mouse line develops prostate adenocarcinoma and neuroendocrine carcinoma with metastatic potential. Cancer Res. 2001 Mar 1;61(5):2239-49. PubMed PMID: 11280793.

[199] Abate-Shen C, Banach-Petrosky WA, Sun X, Economides KD, Desai N, Gregg JP, et al. Nkx3.1; Pten mutant mice develop invasive prostate adenocarcinoma and lymph node metastases. Cancer Res. 2003 Jul 15;63(14):3886-90. PubMed PMID: 12873978.

[200] Smolinski J. Dietary Chemoprevention Studies in Preclinical Models of Prostate Cancer: Bioactive Lipids and Vitamin D. PhD Thesis. 2011. Ohio State University.

[201] Allen NE, Key TJ, Appleby PN, Travis RC, Roddam AW, Tjonneland A, et al. Animal foods, protein, calcium and prostate cancer risk: the European Prospective Investigation into Cancer and Nutrition. Br J Cancer. 2008 May 6;98(9):1574-81. PubMed PMID: 18382426.

[202] Multigner L, Ndong JR, Oliva A, Blanchet P. Environmental pollutants and prostate cancer: epidemiological data. Gynecol Obstet Fertil. 2008 Sep;36(9):848-56. PubMed PMID: 18693059. 
[203] United States Food and Drug Administration. 2009. Available from: http:// www.fda.gov/Safety/MedWatch/SafetyInformation/Safety-relatedDrugLabelingChanges/ucm155404.htm.

[204] AHP Limited. Datapharm Communication Inc.; 2008 [cited 2012]. Available from: http://www.medicines.org.uk/emc/medicine/10312/spc.

[205] Dey E, Nathan V. FDA approves Amarin's heart pill. Menon, R (editor). Reuters. 2012 July 26. Available from: http://www.reuters.com/article/2012/07/26/us-amarin-fdavascepa-idUSBRE86P1SX20120726.

[206] Amarin Corporation. Amarin's AMR101 Phase 3 ANCHOR Trial Meets all Primary and Secondary Endpoints with Statistically Significant Reductions in Triglycerides at Both 4 Gram and 2 Gram Doses and Statistically Significant Decrease in LDL-C: Acquire Media. 2011. Available from: http://investor.amarincorp.com.

[207] Epanova ${ }^{\circledR}$ for Lowering Very High Triglycerides (EVOLVE). U.S. National Institutes of Health. 2012. Available from: http://clinicaltrials.gov/ct2/show/NCT01242527.

[208] Simopoulos AP. Evolutionary aspects of the dietary omega-6:omega-3 fatty acid ratio: medical implications. World Rev Nutr Diet. 2009;100:1-21. PubMed PMID: 19696523.

[209] Food and Nutrition Board. A Report of the Panel on Macronutrients, Subcommittees on Upper Reference Levels of Nutrients and Interpretation and Uses of Dietary Reference Intakes, Standing Committee on the Scientific Evaluation of Dietary Reference Intakes; Dietary Reference Intakes for Energy, Carbohydrate, Fiber, Fat, Fatty Acids, Cholesterol, Protein, and Amino Acids (Macronutrients). 2005. The National Academies Press, Washington, DC. Available at: http://www.nap.edu/openbook.php?record_id $=10490$ \&page $=589$

[210] Kris-Etherton PM, Grieger JA, Etherton TD. Dietary reference intakes for DHA and EPA. Prostaglandins, Leukotrienes and Essential Fatty Acids. 2009 81(2-3):99-104.

[211] Yu H, Rohan T. Role of the insulin-like growth factor family in cancer development and progression. J Natl Cancer Inst. 2000 Sep 20;92(18):1472-89. PubMed PMID: 10995803.

[212] Huizen IV, Wu G, Moussa M, Chin JL, Fenster A, Lacefield JC, et al. Establishment of a serum tumor marker for preclinical trials of mouse prostate cancer models. Clinical Cancer Research. 2005 Nov 1;11(21):7911-9. PubMed PMID: 16278416.

[213] Langdon S. Cancer Cell Culture: Methods and Protocols. 2004: 225-9. Humana Press. ISBN-10: 1588290794 ISBN-13: 978-1588290793.

[214] Schley PD, Brindley DN, Field CJ. (n-3) PUFA alter raft lipid composition and decrease epidermal growth factor receptor levels in lipid rafts of human breast cancer cells. J Nutr. 2007 Mar;137(3):548-53. PubMed PMID: 17311938. 
[215] Ma DW, Ngo V, Huot PS, Kang JX. N-3 polyunsaturated fatty acids endogenously synthesized in fat-1 mice are enriched in the mammary gland. Lipids. 2006 Jan;41(1): 35-9. PubMed PMID: 16555469.

[216] Hjartaker A, Lund E, Bjerve KS. Serum phospholipid fatty acid composition and habitual intake of marine foods registered by a semi-quantitative food frequency questionnaire. Eur J Clin Nutr. 1997 Nov;51(11):736-42. PubMed PMID: 9368807.

[217] Kobayashi M, Sasaki S, Kawabata T, Hasegawa K, Akabane M, Tsugane S. Single measurement of serum phospholipid fatty acid as a biomarker of specific fatty acid intake in middle-aged Japanese men. Eur J Clin Nutr. 2001 Aug;55(8):643-50. PubMed PMID: 11477462.

[218] Chajes V, Hulten K, Van Kappel AL, Winkvist A, Kaaks R, Hallmans G, et al. Fattyacid composition in serum phospholipids and risk of breast cancer: an incident casecontrol study in Sweden. Int J Cancer. 1999 Nov 26;83(5):585-90. PubMed PMID: 10521790.

[219] Folch J, Lees M, Sloane Stanley GH. A simple method for the isolation and purification of total lipides from animal tissues. J Biol Chem. 1957 May;226(1):497-509. PubMed PMID: 13428781. 